\title{
Štruktúry typu schola v Pompejách - symbol a ukážka moci príslušníkov pompejskej aristokracie na príklade štruktúr určených na odpočinok
}

\section{Schola-type structures in Pompeii - a symbol and display of the power of pompeian aristocracy on the examples of structures designed for rest}

\section{Miriam Molnárová}

\begin{abstract}
Abstrakt
Predložený článok bude pojednávat' o polkruhovitých štruktúrach typu schola, ktoré sa nachádzali $\checkmark$ tesnej blízkosti brán na mestských nekropolách $v$ Pompejách a ich funkcia bola určená primárne na odpočinok v rámci funerálneho priestoru. Datovanie schol spadá na prelom letopočtu do obdobia tzv. raného principátu. Predlohu týchto štruktúr je možné nájst' v oblasti východného Stredomoria už v období helenizmu, ktoré sú známe ako exedry. Pozornost' bude venovaná najmä osobám, ktorým boli zmienené scholy dedikované alebo sa o ich výstavbu pričinili. Nahliadnuté bude na ich život, kultúrny pôvod, spoločenské postavenie a úradné či kňazské funkcie v rámci mesta na základe dochovaných archeologických a epigrafických dokladov. V spojitosti s exedrami vo východnom Stredomorí budú rámcovo popísané vybrané príklady na základe ich funkčného alebo topografického zaradenia.
\end{abstract}

\section{Kl'účové slová}

Schola, Pompeje, Raný principát, Exedra, Helénizmus, východné Stredomorie

\begin{abstract}
The presented article is treating semicircular schola type structures, that were located in proximity of the gates of the city necropoleis in Pompeii. Their function was primarily meant to be resting spots within funeral temenos. As to dating of the schola type structures, these were constructed in the 1st centuries, both $B C$ and $A D$, during the period of the Early Principate. Predecessors of these structures can be found in the Eastern Mediterranean already in the period of Hellenism and are known as exedrae. This article is focusing especially on personae to whom the mentioned scholae were dedicated or who contributed to their construction. Their life, cultural origin, social status, executive or priestly functions within the city based on preserved archaeological and epigraphic documents are inspected. Among the exedrae in the Eastern Mediterranean, some examples are selected and considering their functional or topographical classification.
\end{abstract}

\section{Key words}

Schola, Pompeii, Early Principate, Exedra, Hellenism, eastern Mediterranean 


\section{1. Úvod do problematiky, metodo- lógia a výskumné otázky}

Vd’aka neslávne známemu výbuchu Vezuvu v roku 79 n.l. Pompeje fascinujú a pritahujú pozornost’ ako antické mesto zmrazené v čase už niekol'ko generácií archeológov, historikov, umelcov ale i laickú verejnost'. Výskumy, ktoré započali v polovici 18. storočia (Cooley - Cooley 2004, 192) a ktoré pokračujú dodnes, odkryli a umožnili skúmat’ už väčšiu čast mestskej zástavby a prilahlé nekropole. Napriek výskumom, ktoré trvajú už bezmála takmer tri storočia, sa tu stále nachádzajú objekty, ktorým dodnes nebola venovaná väčšia pozornost́. Presne takýmito štruktúrami sú i takzvané scholy, ktoré sa nachádzajú na nekropolách za mestskými bránami, s výnimkou scholy umiestnenej na tzv. Trojuholníkovom fóre. Ide o kamenné lavice $\mathrm{v}$ tvare polkruhu, ojedinele v tvare štvrtiny kruhu, ktoré pozostávajú z pódia či bázy $\mathrm{z}$ väčších kamenných blokov, na ktorom sú umiestnené úzke tufové dosky. Tie tvarujú samotnú lavič$\mathrm{ku}$ /lavicu s vyvýšeným kamenným operadlom spolu s postranným zdobením operadiel s motívom končatiny s pazúrom, ktoré bývajú identifikované ako levie či gryfie (James - Dillon 2015, 410). Podla ustálených názorov spadá konštrukcia schol výlučne do augustovského obdobia (27 p.n.l. - 14 n.l.), ojedinele do obdobia vlády cisára Tiberia (14 n.1. - 37 n. 1.) (Campbell 2015, 49). Aj napriek tomu, že tento článok bude pojednávat o problematike zmienených schol, jadro tejto práce sa bude zaoberat’ osobami, ktoré sa o výstavbu týchto štruktúr zaslúžili alebo ktorým boli priamo dedikované.

V Pompejách je doložených desat stavieb, ktoré sú identifikované ako scholy (Obr. 1). Ide o dve štruktúry na nekropolách za Herkulánejskou bránou (Obr. 2), jednu za Vesuvijskou bránou (Obr. 3), dve za Nolskou bránou (Obr. 4) a tri za Stabijskou bránou (Obr. 5) (Campbell 2015, 49). Ďalšia štruktúra identifikovaná ako schola a jediná v rámci mestskej zástavby je schola na Trojuholníkovom fóre (Obr. 6) (Fiorelli 1875, 36). Posledná identifikovaná stavba monumentálneho rázu, na ktorej je umiestnená polkruhová štruktúra podobná pompejským scholám, je hrobka Eumachie, ktorá sa nachádza na nekropole za Nocerijskou bránou (Campbell 2015, 115). Tento počet uzatvára a navyšuje neidentifikovaná polkruhová štruktúra, ktorá sa taktiež nachádza za Nocerijskou bránou (Obr. 7). V prípade poslednej zmienenej štruktúry je však otázne, či sa jednalo o scholu, ked’že sa táto štruktúra javí byt nedokončenou či výrazne poškodenou a je bez akejkolvek dedikácie. Do dnešného dňa vyšla jediná ucelená publikácia zaoberajúca sa scholami od Lydy Borelli v roku 1937 (Borelli 1937). Táto publikácia však bohužial' nepopisuje všetkých jedenást štruktúr a vynecháva z popisu Eumachinu hrobku a neidentifikovanú polkruhovú štruktúru. Dôvodom totiž je, že sa obe nachádzajú na nekropole za Nocerijskou bránou, ktorá bola skúmaná až v pätdesiatych rokoch minulého storočia.

V naviazanosti na výkonné úradnícke funkcie spomenuté v nasledujúcej kapitole, ktorá sa venuje osobám spojených s výstavbou schol, bude používaná nasledovná latinská terminológia vychádzajúca z dochovaných dedikačných nápisov. Termín ordo decurionum bude odkazovat̉ na tzv. mestskú radu či senát, ktorej člen sa nazýval decurio. V kontexte dedikačných nápisov sa na scholách objavujú venovacie formule ex decreto decurionum, ktoré dokladajú, že daná štruktúra bola postavená z nariadenia rady $d e$ curiones. Druhým pojmom, ktorý bude v práci spomenutý bude termín aedil, ktorý označuje jedného z dvoch nižších úradníkov, ktorí boli volení opakovane každý rok. Tretím termínom bude označenie pozície duovir/duumvir. V tomto prípade ide znovu o dvojicu každoročne volených úradníkov, avšak vyššieho postavenia a s väčšími právomocami ako aedil. Ďalší termín používaný v práci odkazuje na dvojicu najvyššie 


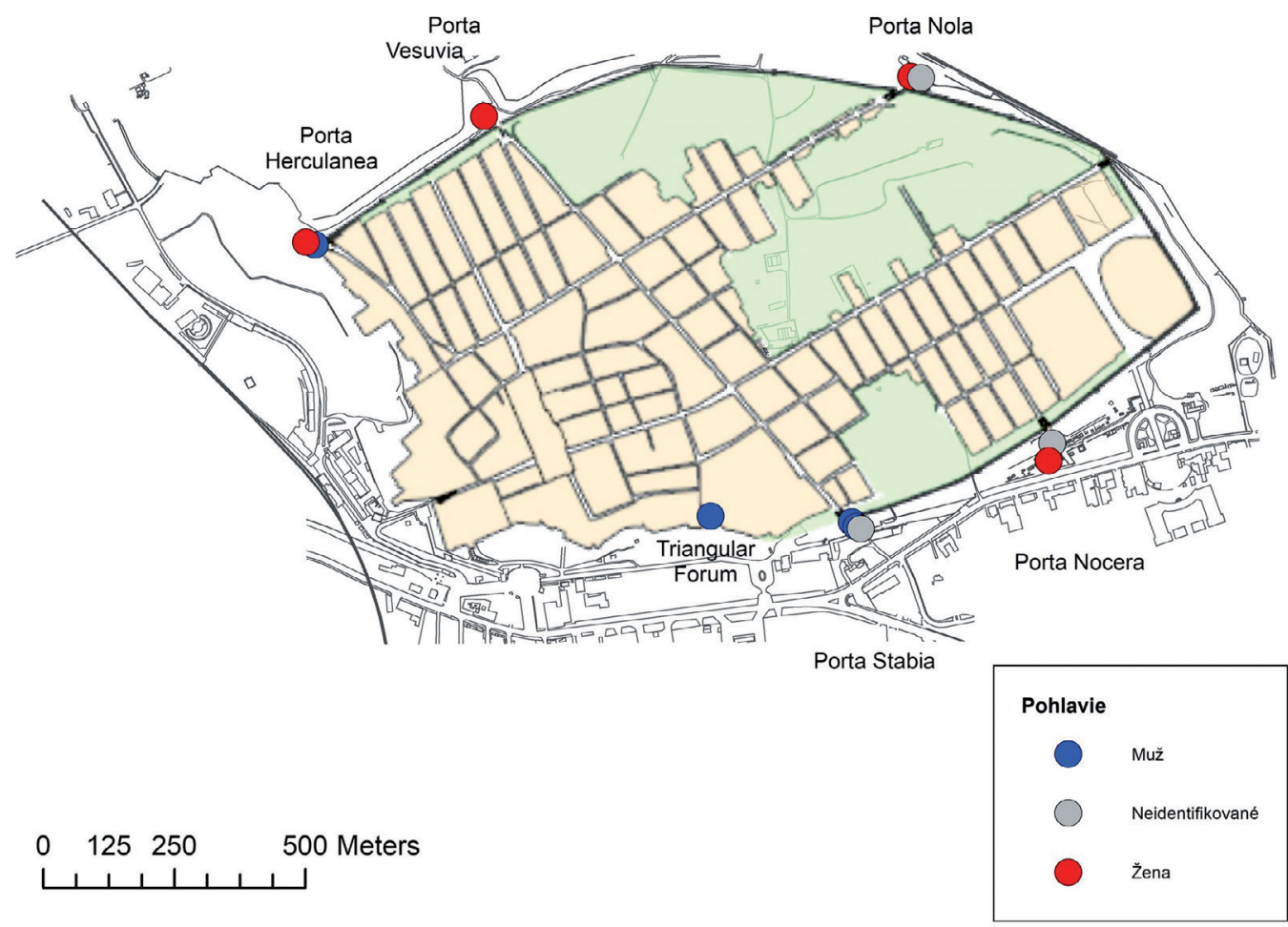

Obr. 1: Umiestnenie jednotlivých schol v rámci Pompejí. Farebné vyznačenie označuje pohlavie jednotlivých osôb, ktorým boli scholy dedikované. Zdroj: Modifikované podl'a Dobbins, J. J. - Foss, P. 2008: The World of Pompeii. CD príloha.

Fig. 1: Location of individual scholae in Pompeii. Different colours signify the sex of individual persons to whom the scholae were dedicated (modified after Dobbins - Foss 2008).

postavených úradníkov zvaných quinquennales. Do funkcie bývali volení každých pät rokov a okrem dozerania na chod verejného úradu a cenzu ${ }^{1}$ mali navyše ako jediní právomoc rozhodovat' o prijatí a vylúčení členov z rady ordo decuriones. Postup v jednotlivých funkciách bol hierarchizovaný a tým pádom každý občan, nárokujúci si na titul duumvira musel odslúžit ako aedil, rovnako ako v prípade nároku na titul quinquenalla. Osoby uchádzajúce sa o tento titul už za sebou museli mat' službu vo funkcií duumvira. Posledný termín, ktorý bude v práci zmienený, je čestný titul udelovaný zvlášt cte- ným a významným občanom Rímskej ríše, ktorý je charakteristický pre obdobie vlády Augusta. Jeho latinský názov znie Tribunus militum $a / a b$ populo a vol’ne je ho možné preložit ako vojenský tribún (volený) z poverenia l'udu (Franklin 2008, 522).

Bude vynaložená snaha zodpovedat' niekol'ko nasledujúcich otázok, ktoré v prípade problematiky štruktúr typu schola vyvstávajú. Tie sú spojené predovšetkým s osobami, ktorým tieto štruktúry boli dedikované alebo sa o ich výstavbu pričinili. Bola stavba schol spojená iba s najvplyvnejšími osobami v rámci pompejskej 

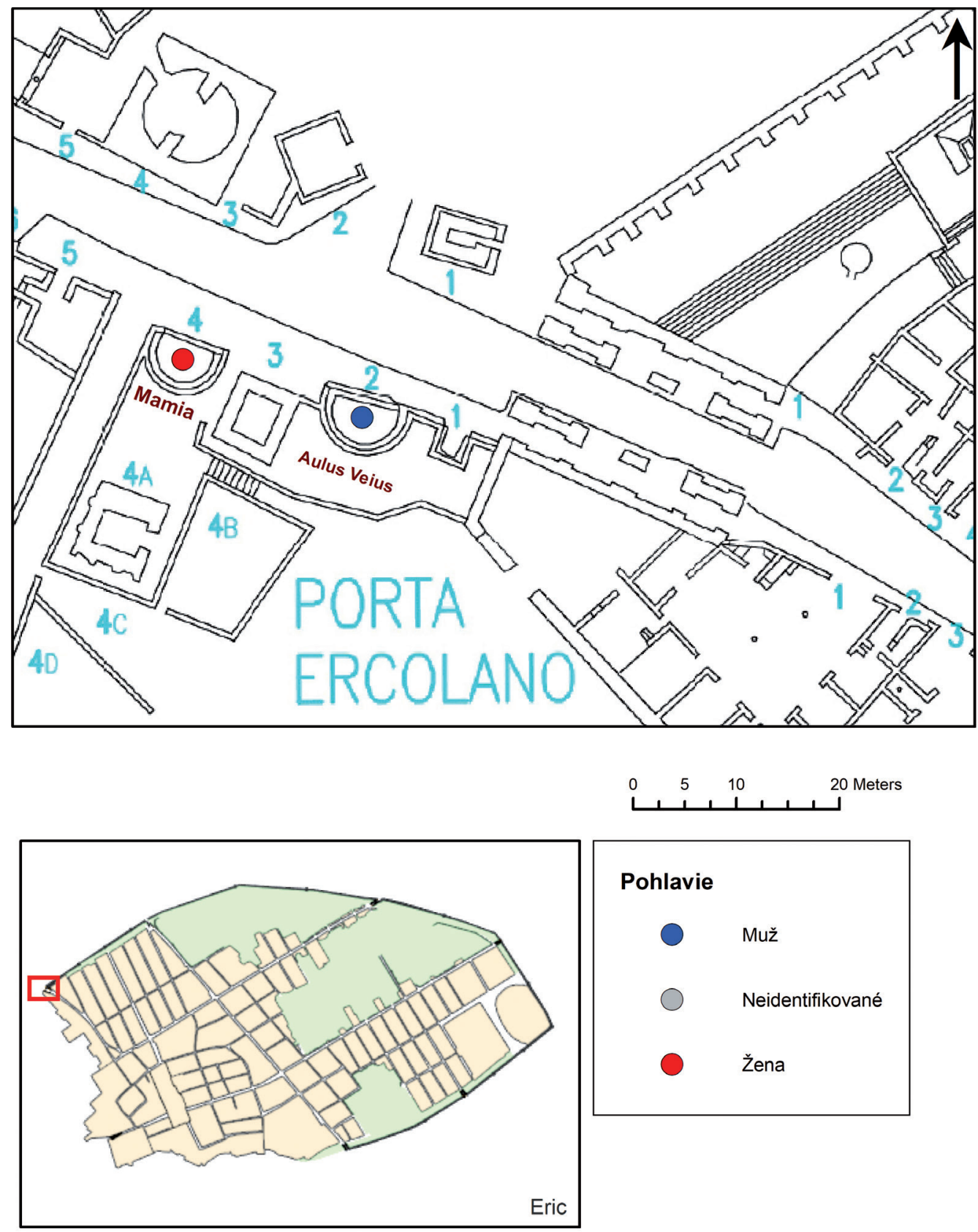

Pohlavie

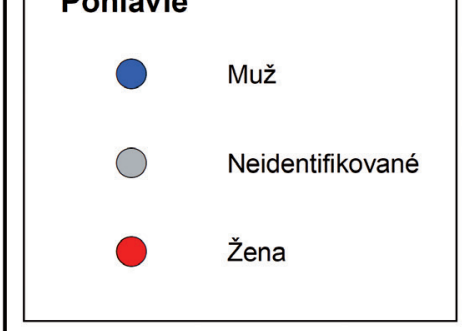

Obr. 2: Pohl'ad na scholu Aula Veia a Mamie za bránou Herkuláneou. Farebné vyznačenie označuje pohlavie jednotlivých osôb, ktorým boli scholy dedikované. Zdroj: Modifikované podl'a Dobbins, J. J. - Foss, P. 2008: The World of Pompeii. CD príloha.

Fig. 2: A view of the Schola of Aulus Veius and Schola of Mamia outside the Herculaneum Gate. Different colours signify the sex of individual persons to whom the scholae were dedicated (modified after Dobbins - Foss 2008). 

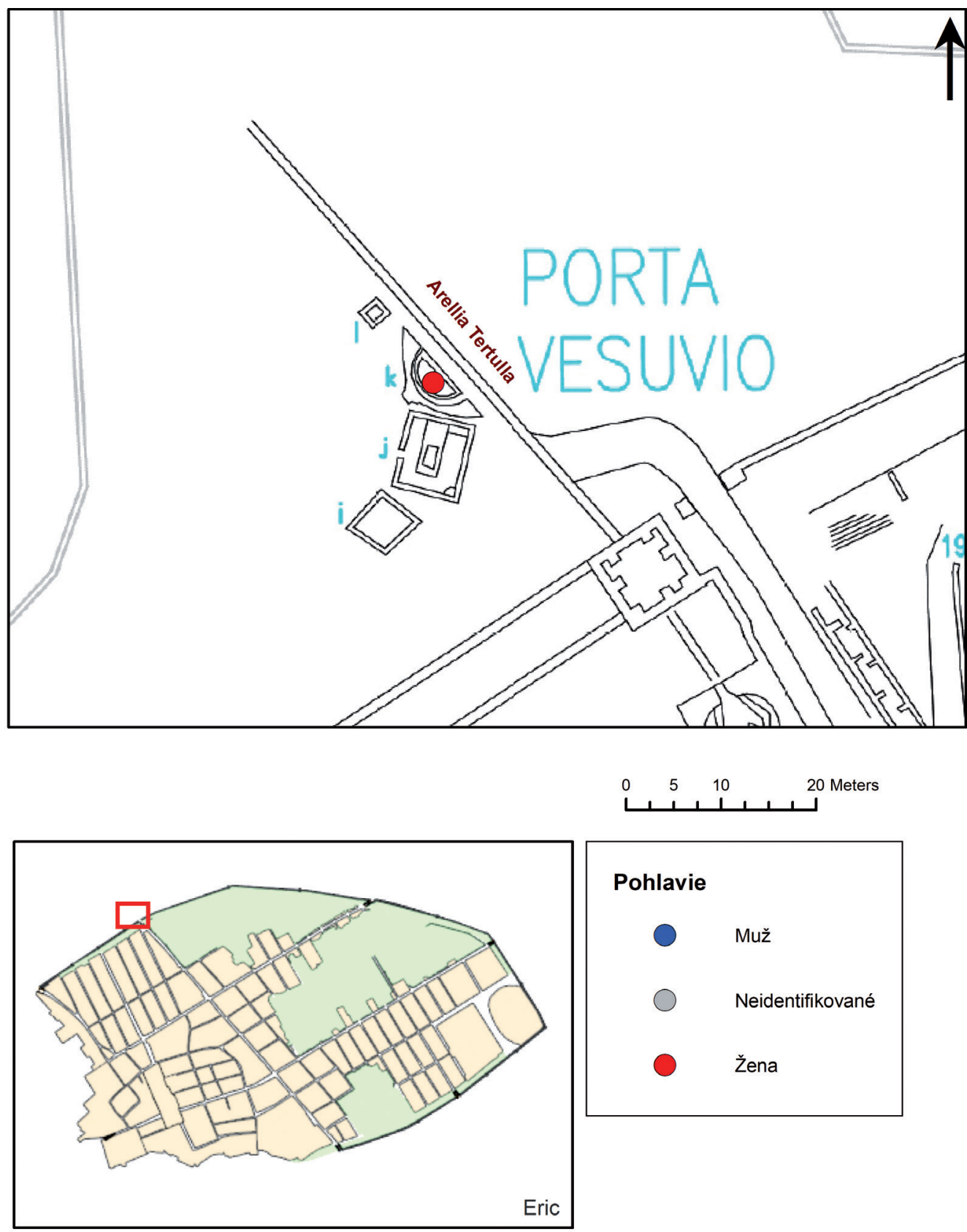

Obr. 3: Pohl'ad na scholu Arellie Tertully za bránou Vesuviou. Farebné vyznačenie označuje pohlavie jednotlivých osôb, ktorým boli scholy dedikované. Zdroj: Modifikované podl'a Dobbins, J. J. - Foss, P. 2008: The World of Pompeii. CD príloha.

Fig. 3: A view of the Schola of Arellia Tertulla outside the Vesuvian Gate. Different colours signify the sex of individual persons to whom the scholae were dedicated (modified after Dobbins - Foss 2008). 

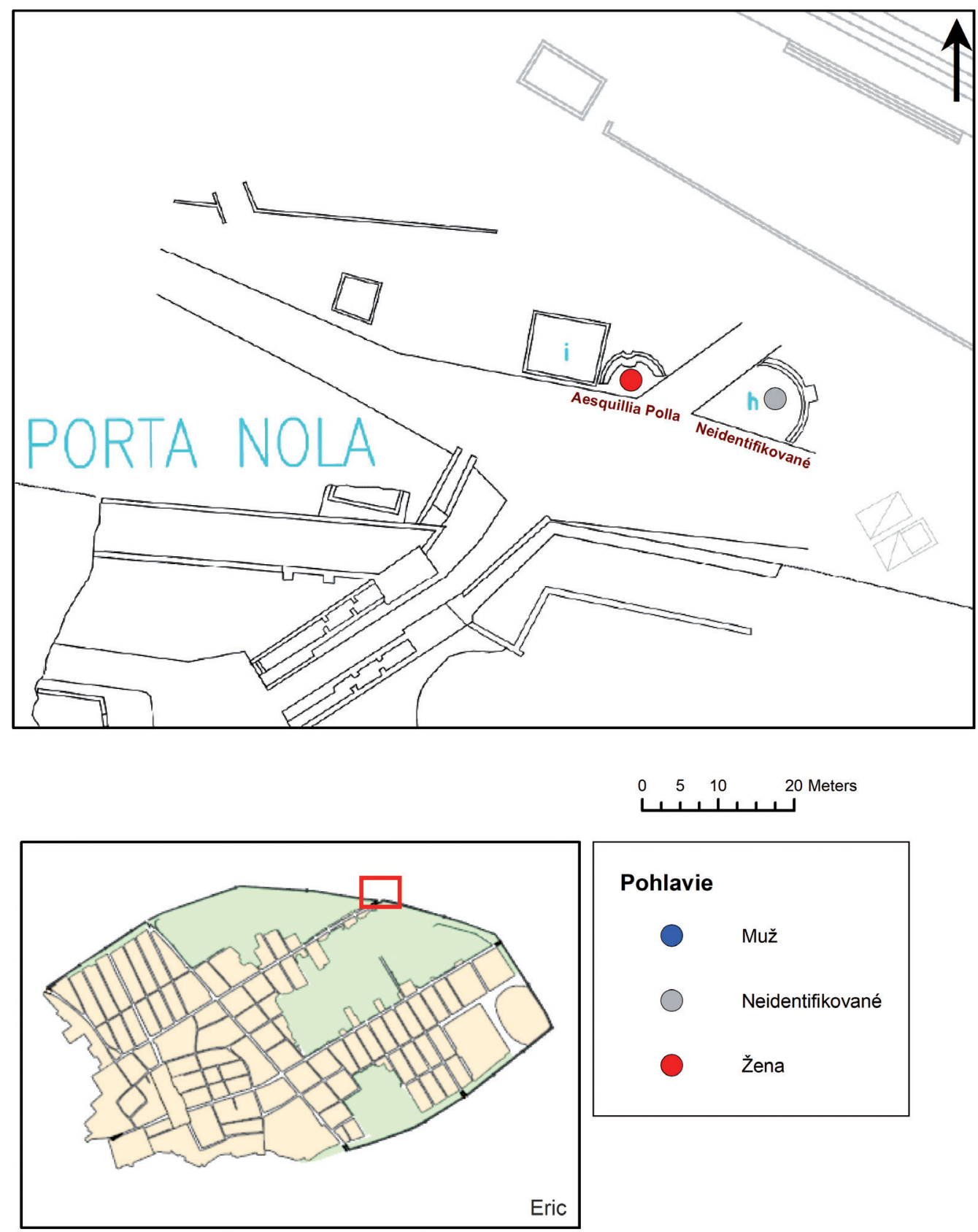

Obr. 4: Pohl'ad na scholu Aesquillie Polly a scholu bez dedikácie za bránou Nolou. Farebné vyznačenie označuje pohlavie jednotlivých osôb, ktorým boli scholy dedikované. Zdroj: Modifikované podla Dobbins, J. J. - Foss, P. 2008: The World of Pompeii. CD príloha.

Fig. 4: A view of the Schola of Aesquillia Polla and a schola without dedication outside the Nola Gate. Different colours signify the sex of individual persons to whom the scholae were dedicated (modified after Dobbins Foss 2008). 

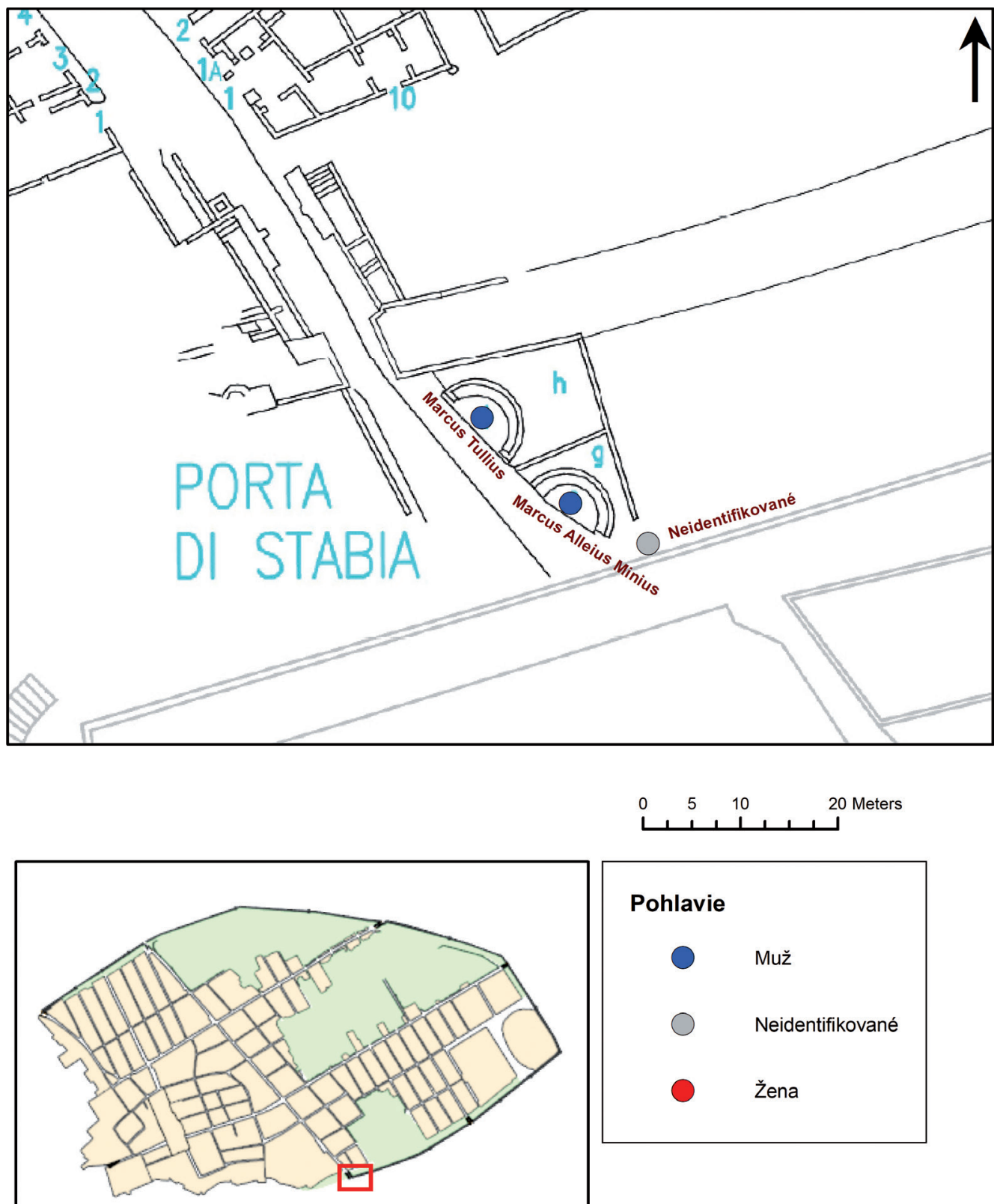

Pohlavie

Muž

Neidentifikované

Žena

Eric

Obr. 5: Pohl'ad na scholy Marca Tullia a M. Alleia Minia a scholu bez dedikácie. Farebné vyznačenie označuje pohlavie jednotlivých osôb, ktorým boli scholy dedikované. Zdroj: Modifikované podla Dobbins, J. J. - Foss, P. 2008: The World of Pompeii. CD príloha.

Fig. 5: A view of the Schola of Marcus Tullius, Schola of Marcus Alleius Minius and a schola without dedication. Different colours signify the sex of individual persons to whom the scholae were dedicated (modified after Dobbins - Foss 2008). 

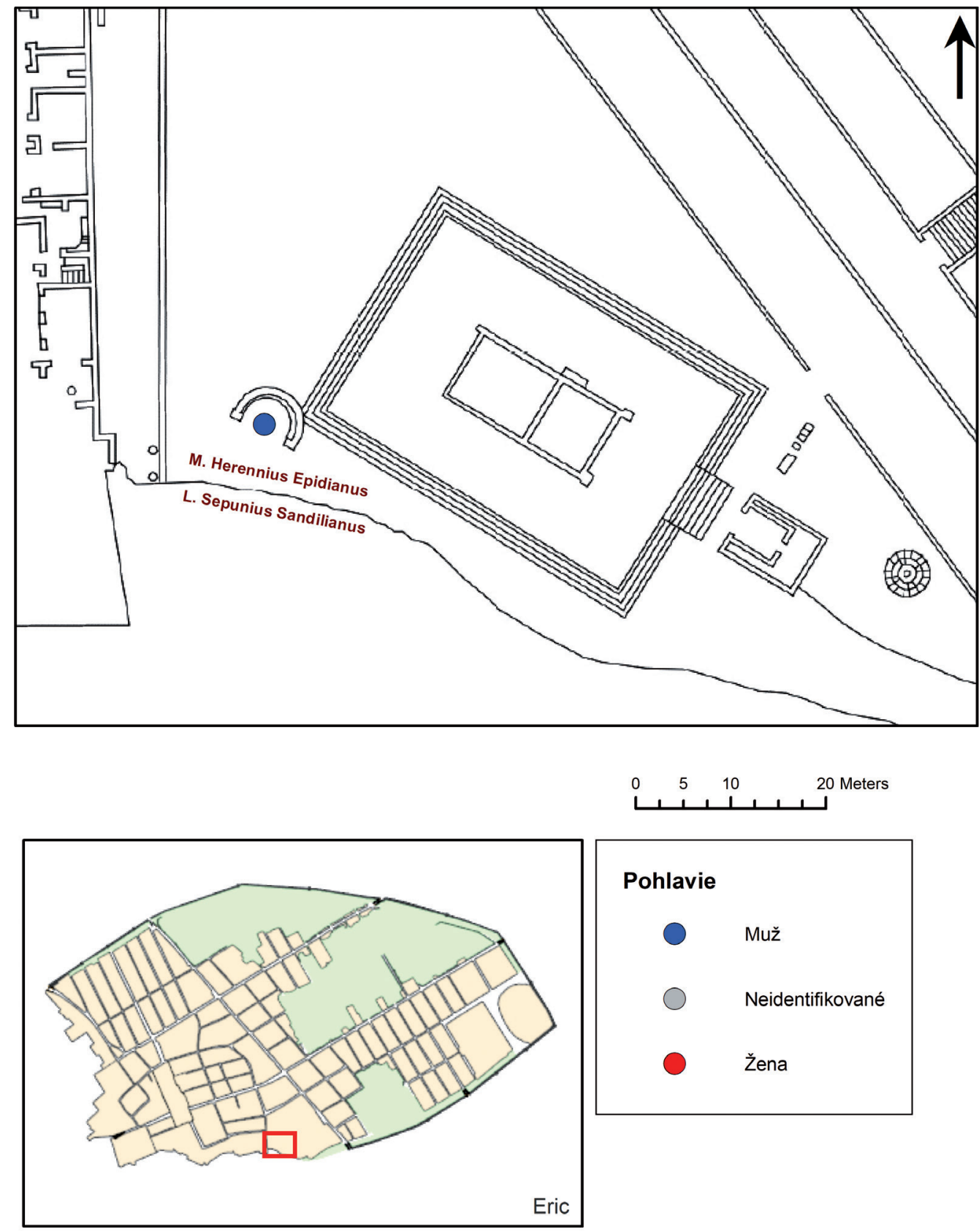

Pohlavie

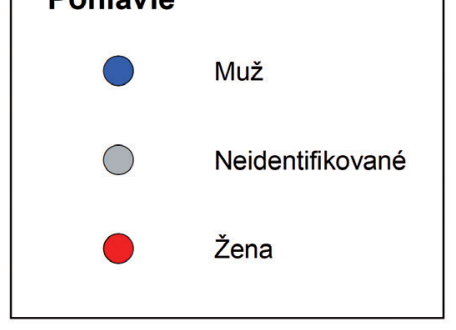

Obr. 6: Pohl'ad na scholu na Trojuholníkovom fóre. Farebné vyznačenie označuje pohlavie jednotlivých osôb, ktoré sa o výstavbu tejto scholy zaslúžili. Zdroj: Modifikované podl'a Dobbins, J. J. - Foss, P. 2008: The World of Pompeii. CD príloha.

Fig. 6: A view of a schola in the Triangular Forum. Different colours signify the sex of individual persons who sponsored the construction of this schola (modified after Dobbins - Foss 2008). 

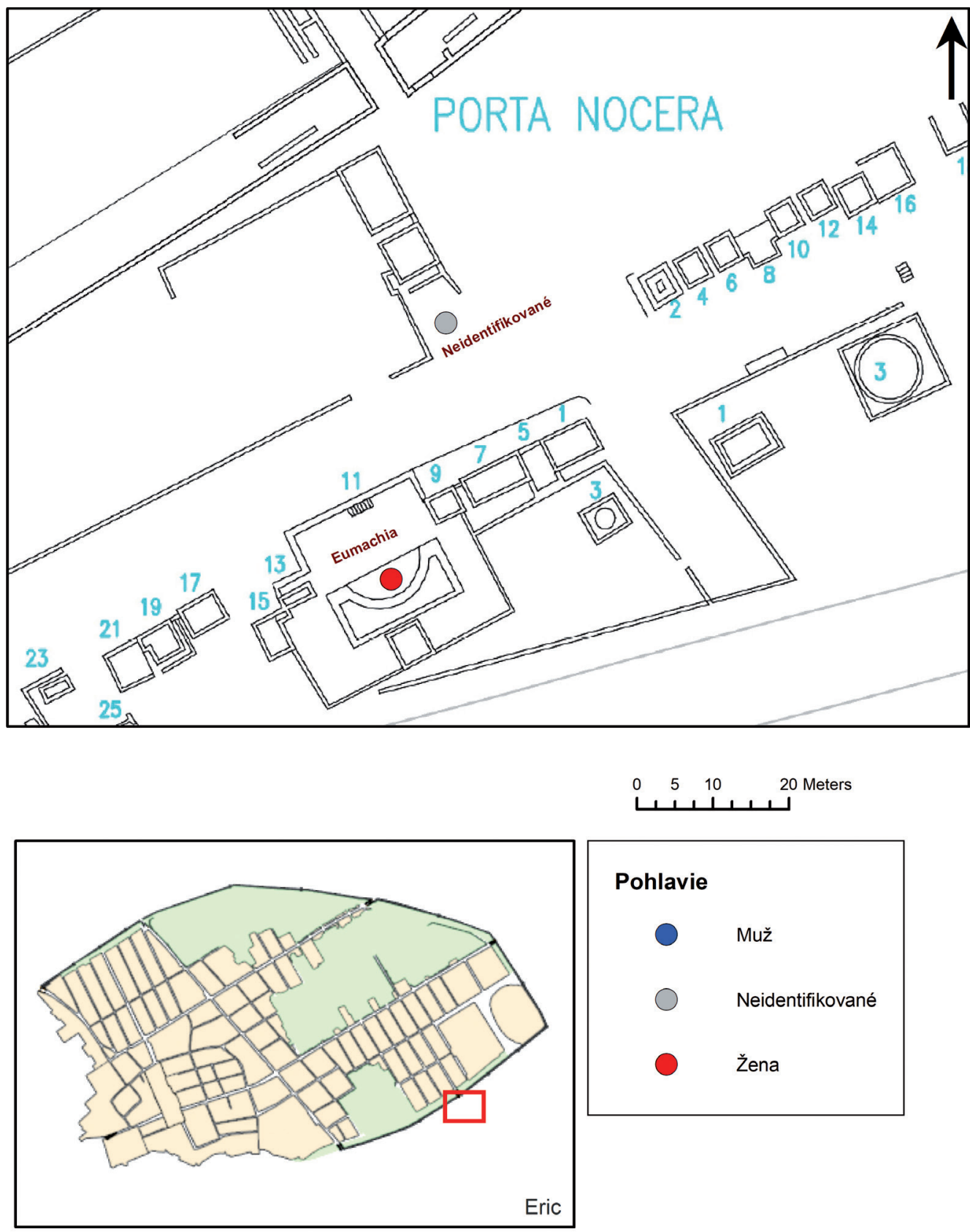

Obr. 7: Pohl'ad na neidentifikovanú štruktúru a Eumachinu hrobku za bránou Nocerou. Farebné vyznačenie označuje pohlavie jednotlivých osôb, ktorým boli scholy dedikované. Zdroj: Modifikované podl'a Dobbins, J. J. Foss, P. 2008: The World of Pompeii. CD príloha.

Fig. 7: A view of an unidentified structure and the Tomb of Eumachia outside the Nocera Gate. Different colours signify the sex of individual persons to whom the scholae were dedicated (modified after Dobbins - Foss 2008). 
aristokracie na základe ich postavenia a prípadnej stavebnej činnosti v rámci Pompejí? Nepodliehala výstavba týchto štruktúr konkrétnemu kultúrnemu pôvodu daných osôb? V neposlednom rade bude nahliadnuté na otázku datovania schol a na problematiku ohladom ustáleného radenia týchto štruktúr medzi hrobky.

\section{História vývoja a kultúrneho osídlovania Pompejí}

V kontexte poslednej otázky ohl'adom osôb spojených s výstavbou schol sa nasledujúca čast’ venuje histórií osídl'ovania Pompejí. Vzhl’adom na kultúrnu pestrost' obyvatel'stva, ktorou Pompeje disponovali, je v samotnej kapitole o scholách vynaložená snaha zistit, či výstavba týchto štruktúr nebola viazaná iba na jeden konkrétny kultúrny pôvod daných osôb. Z tohto dôvodu je preto nutné najprv stručne popísat históriu osídlovania Pompejí obyvatel'stvom Etruského, Gréckeho a Kampánskeho pôvodu. Aj napriek tomu, že sú Pompeje považované za mesto v rámci Rímskej ríše, je otázne, či bolo toto mesto i na sklonku svojej existencie skutočne rímskym. Už v antických spisoch Livia ${ }^{2}$, Strabóna ${ }^{3}$ a Plinia st. ${ }^{4}$ je možné dočítat sa o nadmiernej fertilite $\mathrm{v}$ oblasti Neapolského zálivu a mocenských záujmoch spomenutých populácií, ktoré sa usilovali o ovládnutie tohto územia. Bohužial' sa zmienené práce postupnému osídlovaniu Pompejí venujú iba skratkovite a je možné sa v nich dočítat o striedaní Oskov, Samnitov, Etruskov a Grékov na tomto území, bez bližšej časovej špecifikácie. $\mathrm{V}$ rámci práce $\mathrm{s}$ antickými prameňmi treba zostávat kritický a obozretný ohladom prednesených informácií z dôvodu rozsiahleho časového odstupu aj niekol'kých storočín ${ }^{2}$ v ktorom zmienené práce vyšli. Pre snahu lepšie pochopit celkovú situáciu ohladom kultúrneho vývoja v Pompejách je preto potrebné pracovat najmä so štúdiami archeológov, historikov a filológov. V nasledujúcich riadkoch bude preto v rámci možnosti popísaný príchod a mocenské súboje Grékov, Etruskov, Samnitsko-Oskánskej populácie a ku koncu 1. storočia p.n.l. i Rimanov, ktorých následkom bolo to, že Pompeje ako také nikdy neboli striktne rímskym latinizovaným mestom.

\subsection{Historický a kultúrny vývoj osídle- nia v oblasti Neapolského zálivu}

Počiatky gréckej kolonizácie Neapolského zálivu siahajú do roku 775 p.n.l., kedy kolonisti prevažne z iónskeho obyvatel'stva (Bartoněk 1975, 19) zakladajú osídlenie Pithekoussai na ostrove Ischia. Toto osídlenie ale krátko nato stráca na pôvodnom význame a už v roku 730 p.n.l. vzniká kolónia na mieste dnešného Kýmé (Tartaron 2014, 1810). Nedlho potom, na prelome 7. a 6. storočia p.n.l. je založený Neapol ako sekundárna kolónia, nesúca názov Neapolis ako „Nové mesto“ (Astour 1985, 27). Hegemónia Grékov na území Neapolského zálivu však dlho nepretrváva a už v 6. storočí p.n.l. o toto územie začínajú mocensky usilovat Etruskovia. Boje medzi Grékmi a Etruskami však nekončia trvalou prevahou ani pre jednu stranu. Naopak ich oslabovanie vytrvalými bojmi podla Astoura dopomáha samnitsko-oskánskemu obyvatel'stvu z vnútrozemných hôr, ktoré na územie Neapolského zálivu prichádza v 5. storočí. Tieto kmene po podmanení si mesta Kýme v roku 421 p.n.l. začínajú postupne ovládat’ a osídlovat väčšinu miest na tomto území, a to i vrátane Pompejí (Astour 1985, 34).

\subsection{Historický a kultúrny vývoj Pompejí}

Ohladom počiatkov osídlovania samotných Pompejí je najväčším problémom rozkol názorov jednotlivých bádatelov, ako antických 


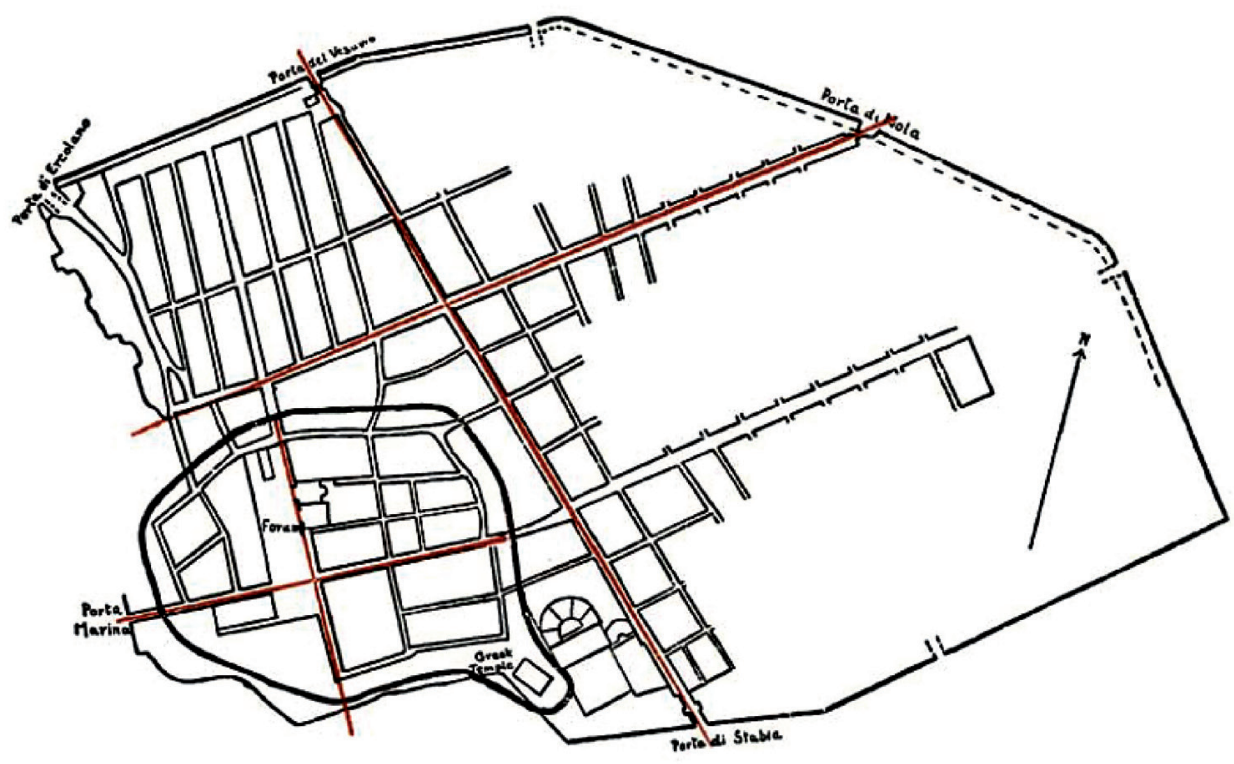

Obr. 8: Plán a umiestnenie starých (Altstadtu) Pompejí s vyznačenými hlavnými cestami na mape dnešného antického mesta. Zdroj: Carrington 1932.

Fig. 8: Plan and localisation of the old city of Pompeii (Altstadt) with marking of the main roads on a map of the classical Roman city (after Carrington 1932).

zmienených vyššie, tak i moderných. Napriek tomuto tvrdeniu však väčšina archeológov a historikov súhlasne tvrdí, že založenie ustáleného osídlenia na území Pompejí nemožno presne datovat. Prevládajúcim názorom, že Pompeje boli založené oskánskym obyvatel'stvom argumentuje väčšina bádatelov minulého storočia (Mau 1904, 8; Mackenzie 1910, 2; Dyer 1870, 30) a to i na základe etymologického významu slova pompe. Diskutabilnosṫ týchto tvrdení však vyvstáva vzhladom na fakt, že tento výraz môže pochádzat ako z oskánskeho jazyka (Richardson 1988, 5) tak i z gréčtiny (Maiuri 1978, 3) pričom v prvom prípade tento názov odkazuje na číslovku pät a v tom druhom na Héraklovú procesiu pri spiatočnej ceste do Grécka (Descoeudres 2008, 9). Similaritu Pompejí so založením Ríma vidí Carpiceci (Carpiceci 1979, 4) a Jashemská (Jashemski 2002, 6), podla ktorých je v pláne starých Pompejí, tzv. Altstadtu (Obr. 8) viditelný výrazný vplyv etruského územného plánovania vo forme usporiadania hlavných ciest cardo a decumana (Carrington 1932, 9). V tomto období, ktoré je datované do rozpätia 8. a 6. storočia p.n.l. tu však podla nálezov keramiky mali spolunažívat obyvatelia prevažne etruského a gréckeho pôvodu (Descoeudres 2008, 15-16) pričom samnitské obyvatel'stvo na toto územie prichádza až na prelome 5. a 4. storočia po bitke u Kýmé v roku 421 p.n.l. (Richardson 1988, 5).

\subsubsection{Historický a kultúrny vývoj Pompejí na základe epigrafických nálezov}

Zavŕšením časti venujúcej sa osídl'ovaniu Pompejí obyvatel'stvom jednotlivých kultúr je nahliadnutie na epigrafické pamiatky, ktoré dokladajú prítomnost Etruskov, Grékov a Kampánskeho obyvatel'stva na území Pompejí. Inskripcie, ktoré sú popísané v tejto časti 
nemajú priamu spojitost’ so štruktúrami typu schola. Napriek tomu ale aspoň útržkovite doplňujú poznanie ohladom histórií vývoja mesta a dokladajú tak spolunažívanie multikultúrneho obyvatel'stva Pompejí od raných počiatkov. Spolunažívanie Grékov a Etruskov v Pompejách dokladajú najmä nálezy nápisov, ktoré sa nachádzali na etruskej keramike typu bucchero a na gréckych čiernofigúrových a červenofigúrových fragmentoch nádob. Tieto nálezy sa kumulovali v oblasti dvoch chrámov datovaných do 6. storočia p.n.l. a to chrámu Apolóna na fóre a Dórskeho chrámu na Trojuholníkovom fóre v priestore tzv. Altstadtu (Giuntioli 1989, 3-12; Bradley 2013, 12). V rámci nelatinských inskripcií je v kontexte nálezov gréckej alfabety potrebné zmienit i výskyt gréckych graffitov krátkych, väčšinou venovacích formuliek spolu s menom - ktoré datačne spadajú 3. storočia p. n.1. (Descoeudres 2008, 26). Touto problematikou sa bližšie Allisonová, podla ktorej malo až $50 \%$ obyvatel'stva Pompejí v mene cognomen gréckeho pôvodu (Allison 2001, 5-6). Najpočetnejšou skupinou nelatinských nápisov sú inskripcie samnitsko-oskánskeho pôvodu, známe ako eítuns (Henderson 2014, 99). Bohužial' tieto nápisy však neosvetlujú dobu príchodu kampánskeho obyvatelstva, vzhladom na fakt, že väčšina týchto nápisov pochádza zo 60tych a 70tych rokov n.l., kedy boli tieto inskripcie prepisované po ničivom zemetrasení z roku 62 n.l. (Adams 2003, 146-147). Doklad nelatinských epigrafických nálezov v Pompejách potvrdzuje tvrdenie, že toto mesto nebolo populačne nikdy homogénne a to ani po začlenení do impéria po roku 80 p.n.l. Romanizácia tohto mesta v 1. storočí p.n.l. ale ani mocenské boje Grékov, Etruskov a Kampáncov v predošlých obdobiach nemuseli mat negatívny vplyv na obyvatel'stvo Pompejí a populácie týchto troch kultúr tu tak nažívali vedla seba.

\section{Scholy}

Pomenovanie schola bádatelia používajú vd’aka dochovanej inskripcii na schole z Trojuholníkového fóra. Toto pomenovanie podla Borelliovej vychádza z gréckeho $\sigma \chi 0 \lambda \eta \mathrm{a}$ v antike označovalo miesto určené na odpočinok ako aj miesto určené na stretnutia a diskusiu filozofov či učitelov so svojimi študentmi (Borelli 1937, 8). Ide o polkruhové, kamenné lavice s prídavnou dekoráciou postranných operadiel formovaných do podoby laby s drápom, ktoré bývajú interpretované ako levie či gryfie (Obr. 9). V roku 1937 vytvorila Borelliová typológiu pompejských schol, ktorá pozostávala z piatich typologických skupín na základe prídavných architektonických prvkov $^{6}$. Prvým typom je polkruhová štruktúra s centrálnym výstupkom zo zadnej strany operadla a murovaným obkolesením, ktorý vymedzoval priestor za scholou. Takýto typ scholy bol dedikovaný Marcovi Tulliovi (Borelli 1937, 28) a Marcovi Alleiovi Miniovi $i^{7}$ za Stabijskou bránou. Druhým typom je jednoduchá polkruhová štruktúra bez prídavných architektonických prvkov. Jediný badatelný prídavok je priehlbina v schode uprostred priesečnice a spoločným prvkom schol v tejto kategórií je dedikačný nápis, ktorý je vytesaný priamo do operadla ${ }^{8}$. Do tohto typu radí scholu Mamie za Herkulánejskou bránou a scholu Marca Alleia Minia ${ }^{9}$ za Stabijskou bránou (Borelli 1937, 26). Do tretej kategórie patrí jediná štruktúra, a síce schola bez dedikácie, ktorá sa nachádza za Nolskou bránou. V tomto prípade ide ojedinele o kamennú štruktúru vo forme štvrtiny kruhu a prídavným kamenným oltárom, ktorý vystupuje nad úroveň scholy uprostred operadla (Borelli 1937, 28). Štvrtý typ je schola vo forme nedokončeného polkruhu s prídavnou architektonickou dekoráciou vo forme stĺpu, ktorý vystupuje nad lavicu uprostred operadla. Do tejto kategórie patrí schola dedikovaná Aesquillii Polle za Nolskou bránou. Piatym a posledným typom je schola 


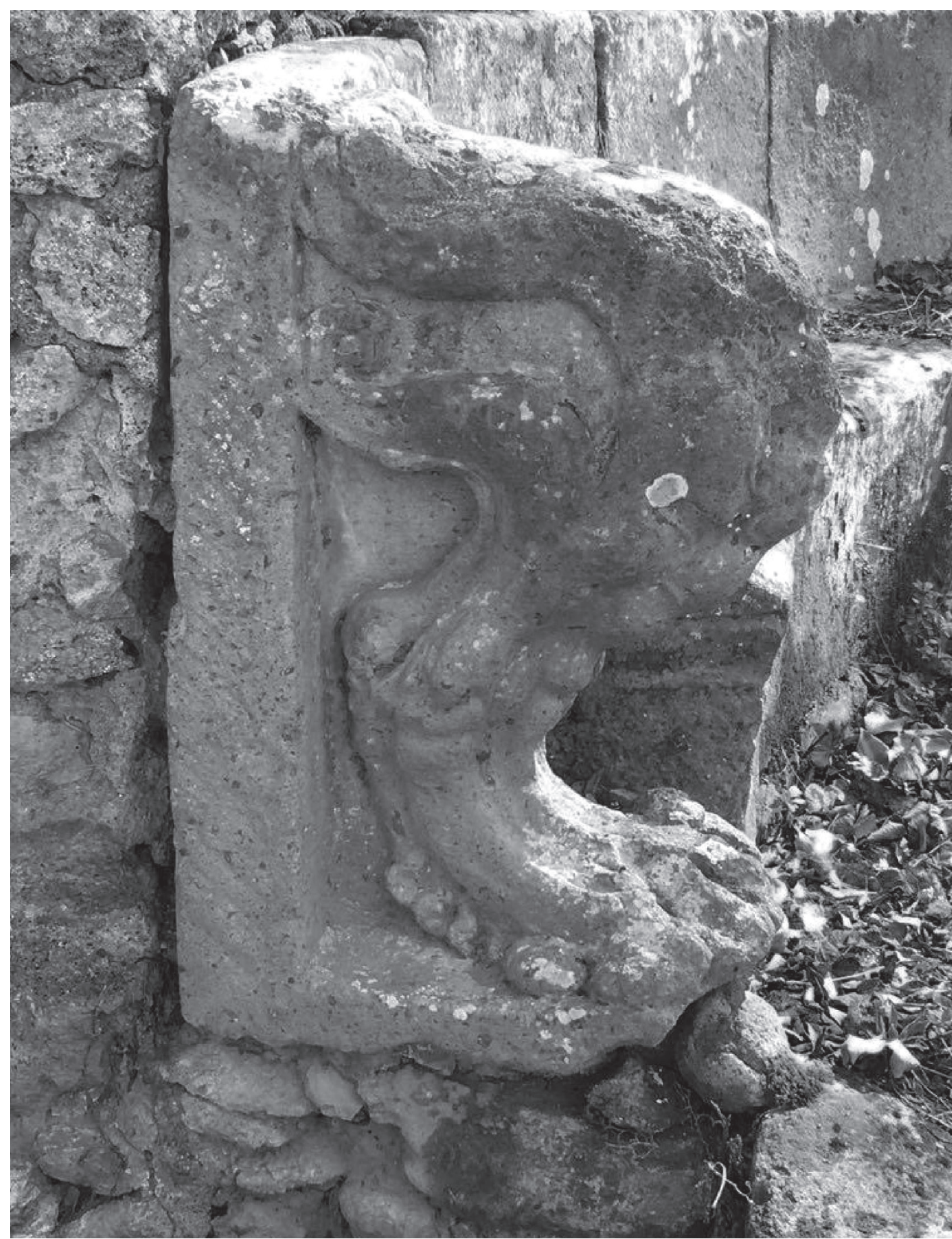

Obr. 9: Detail výzdoby postranných operadiel. Zdroj: Archív autora.

Fig. 9: Detailed view of decoration on the arm rests (archive of the author). 
znovu vo forme polkruhu s centrálnou bázou uprostred zadnej časti operadla, z ktorej opät navyše vystupuje stíp. Rozdiel medzi štvrtým a piatym typom je v umiestnení daného stípu, ktorý v prípade scholy Aesquillie Polly rozdeluje priestor na sedenie svojím umiestnením v prednej časti scholy. Do piatej kategórie patrí schola dedikovaná Arellii Tertulle, ktorá sa nachádza za Vesuvijskou bránou. Do poslednej kategórie Borelliová umiestňuje i scholu dedikovanú Aulovi Veiovi za Herkulánejskou bránou (Borelli 1937, 26-28). Zaradenie poslednej spomenutej scholy do tejto kategórie je ale diskutabilné vzhl'adom na absenciu zmieneného stĺpu. V prípade scholy Aula Veia ide o polkruhovú štruktúru bez akejkolvek pridanej architektonickej dekorácie s výnimkou dekorácie postranných operadiel, ktorou ale disponujú všetky zmienené scholy. Je teda otázne, či by vzhladom na tento fakt nemala táto schola patrit do druhej kategórie, ktorá je zmienená vyššie. Posledná štruktúra, ktorá bola identifikovaná ako schola, je štruktúra, ktorá leží v tesnej blízkosti schol Marca Tullia a Marca Alleia Minia za Stabijskou bránou. Táto štruktúra tu bola identifikovaná počas výskumu koncom 19. storočia (Mau 1890, 278), avšak vzhladom na jej umiestnenie pod obytným domom, nebola možnoste túto scholu dodnes vykopat’ a bližšie preskúmat' (Emmerson 2010, 78).

Práve v prípade neidentifikovanej štruktúry za Nocerijskou bránou vyvstáva otázka, či sa skutočne mohlo jednat o scholu. Identifikácia tejto štruktúry je bohužial' problematická najmä z dôvodu absencie jej popisu v odbornej literatúre. Tento argument by mohlo potvrdit niekol'ko nasledujúcich tvrdení. Prvým je samotné umiestnenie, ktoré je v tesnej blízkosti mestskej brány, tak ako tomu je aj v prípade ostatných schol. Rovnako tvarom vo forme polkruhu táto štruktúra zodpovedá popisu pompejských schol. Táto štruktúra má navyše prídavnú architektonickú dekoráciu vo forme centrálneho zadného výstupku, zadného murovaného obkolesenia a priehlbiny uprostred priesečnice. Všetky zmienené prídavky sa nachádzajú, či už samostatne alebo v kombinácii na konkrétnych scholách ${ }^{10}$ zmienených $\mathrm{v}$ predchádzajúcom odstavci. $\mathrm{Na}$ prvý pohlad je badatelné, že táto štruktúra, či už sa pôvodne malo alebo nemalo jednat o scho$l u$, nie je dokončená. Ako je možné vidiet’ na obrázku (Obr. 10), zachovala sa iba základná báza tejto štruktúry, na ktorú by ale v prípade, že by sa jednalo o scholu, mali byt' ešte nasadené tufové bloky, ktoré by vytvárali priestor na sedenie na vyvýšenej lavici. Je otázne, či je možné uvažovat' o rozsiahlom poškodení tejto štruktúry zemetrasením v roku 62 n.l. alebo o jej nedokončenom stave. $\mathrm{V}$ prípade druhej možnosti by to ale mohlo vyvracat ustálené mienenie, že štruktúry typu schola spadajú výhradne do obdobia raného principátu, konkrétne do rozpätia rokov 27 p.n.1. - 37 n.l.

\subsection{Scholy - hrobky alebo komemora- tívne pamätníky?}

Vzhladom na umiestnenie schol na mestských nekropolách sú tieto štruktúry v literatúre obecne popisované ako hrobky. Jediná štruktúra, ktorá skutočne plnila účel uloženia pozostatkov zosnulých je hrobka, ktorú dala na vlastné náklady postavit Eumachia za Nocerijskou bránou pre seba a svoju rodinu (Cooley - Cooley 2004, 142). Polkruhová štruktúra monumentálneho rázu (vid’ Tab. 1), ktorá je umiestnená na vrchole tejto hrobky, však nemá typické prvky pompejských schol (Campbell 2015, 115). Ide predovšetkým o jej umiestnenie na hrobke, ktoré neumožňovalo prístup k tejto štruktúre širokej verejnosti. Navyše na tejto štruktúre chýba zdobenie postranných operadiel vo forme levej alebo gryfej tlapy a v neposlednom prípade ide o jedinú štruktúru tohto typu, ktorá nebola postavená z poverenia rady decuriones (Scott 2013, 19). Je teda otázne, či je túto štruktúru možné 


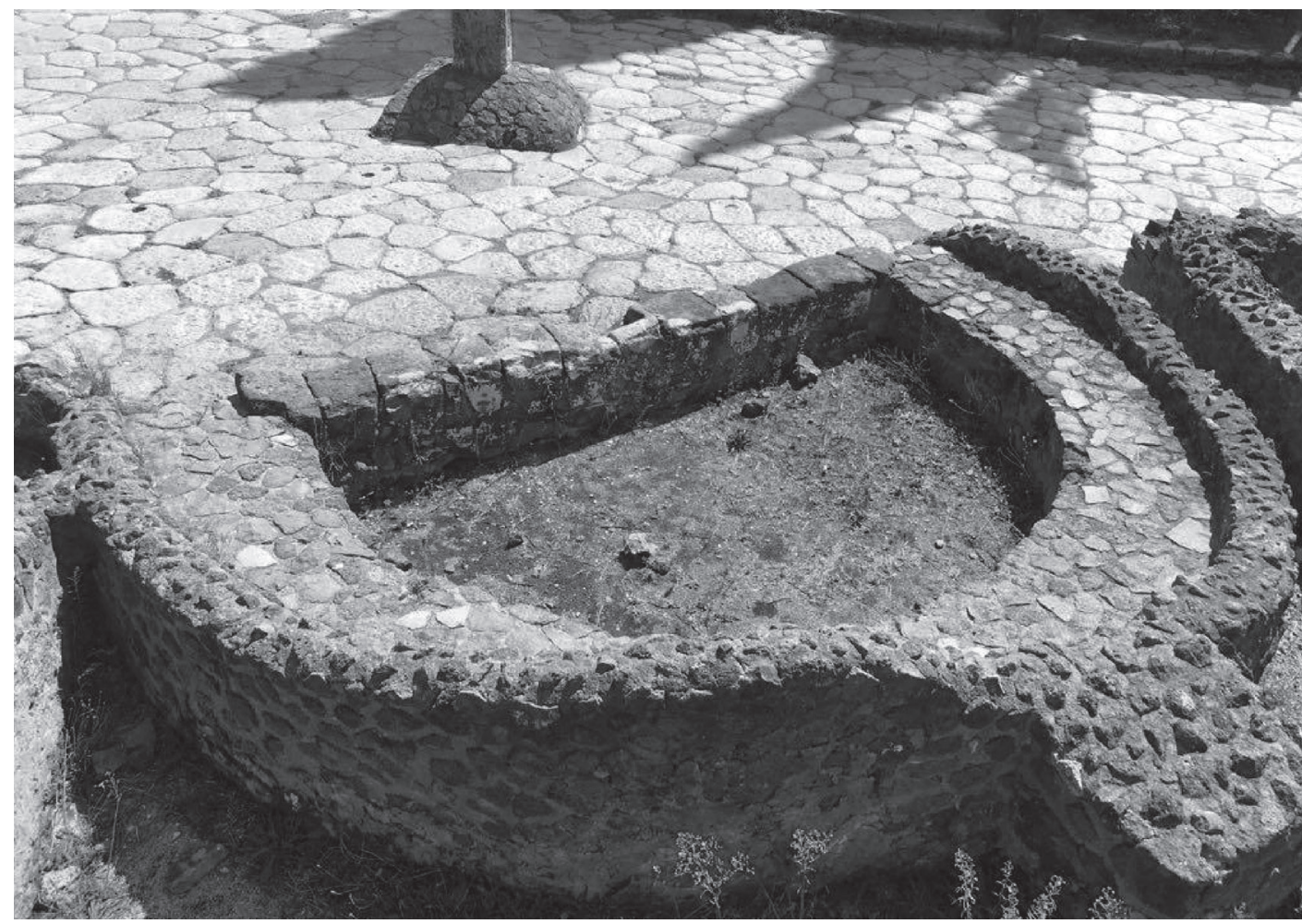

Obr. 10: Pohl'ad na neidentifikovanú štruktúru za bránou Nocerou. Zdroj: Archív autora.

Fig. 10: A view of an unidentified structure outside the Nocera Gate (archive of the author).

označovat ako scholu a či by nebolo vhodnejšie označovat ju ako exedru, po vzore polkruhových exedier $\mathrm{z}$ helenistických miest vo východnom Stredomorí.

V kontexte ostatných štruktúr, ktoré sú označené ako scholy umiestnené na nekropolách nebol dodnes nájdený v okolí jednotlivých schol jediný pohreb. Snahy archeológov identifikovat’ uloženie ostatkov zosnulých sa bohužial ani v jednom prípade nepotvrdili. Najrozsiahlejšie výskumy v otázke umiestnenia kremácie prebehli v rámci priestoru schol za Nolskou a Stabijskou bránou. Za Nolskou bránou sa ako prvý snažil identifikovat umiestnenie kremácie Aesquillie Polly Spano, podla ktorého sa tieto ostatky mohli nachádzat’ v dekoratívnej nádobe, ktorá sa nachádza na vrchole stlipu tejto scholy
(Spano 1910, 393). Táto teória však bola vyvrátená najnovším výskumom Britskej školy v Ríme, ktorá za pomoci GPR ${ }^{11}$ metódy skenovala túto stavbu i nové stratigrafické vrstvy pod touto scholou v híbke, kam Spanov výskum nedosiahol. Ani v tomto prípade však nebol výskum úspešný a miesto uloženia ostatkov Aequillie Polly nebol doložený (Kay - Martin - Albiach 2017, 325). Výskum Britskej školy v Ríme za pomoci GPR metódy sa zameral i na susednú scholu bez dedikácie. Pod úrovňou podlahy tejto scholy boli nájdené drobné anomálie, avšak z dôvodu zachovania pôvodnej stratigrafickej vrstvy boli tieto anomálie ponechané in situ (Kay - Alapont - Albiach 2018, 416). Ďalší výskum, ktorého snahou bolo identifikovanie kremácie v kontexte schol, prebehol za Stabijskou bránou. Na tejto 


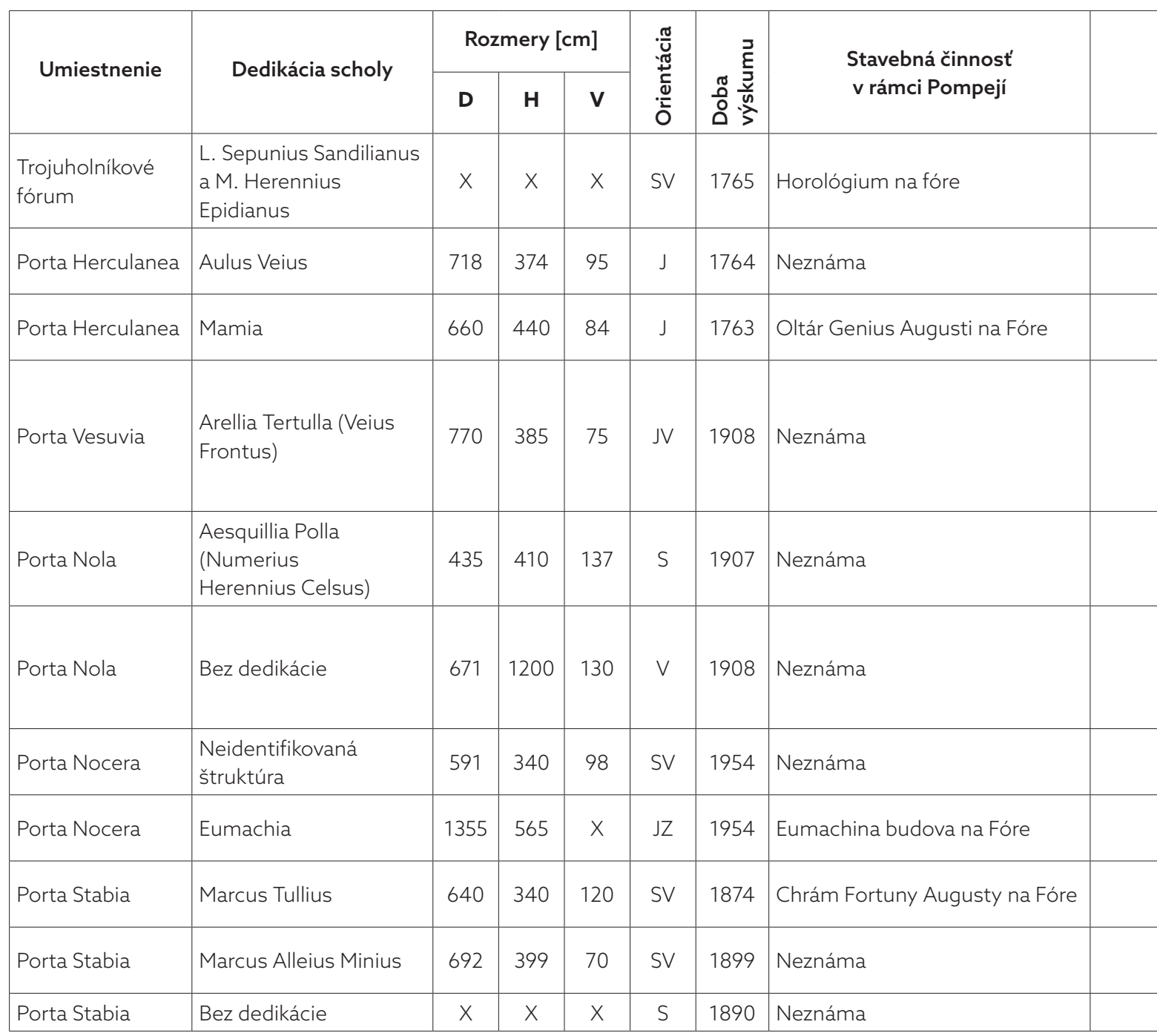

Tab. 1. Sumarizované údaje schol podl'a umiestnenia na jednotlivých nekropolách.

V prípade rozmerov označuje D dĺžku, H híbku a $\vee$ výšku štruktúry.

Tab. 1. Summarized data of schola-type structures according to location on individual necropoleis.

In the case of dimensions - $\mathrm{D}$ denotes the length, $\mathrm{H}$ the depth and $\mathrm{V}$ the height of the structure. 


\begin{tabular}{|c|c|c|}
\hline Titul verejnej funkcie & Kultúrny pôvod osoby (osôb) & Datácia výstavby \\
\hline Duovir, Duovir & $\begin{array}{l}\text { Sepunius - neznámy; } \\
\text { Herennius - oskánsky }\end{array}$ & 30 - 20 p.n.I. (Richardson 1988, 72) \\
\hline $\begin{array}{l}\text { Duovir, Quinquennalis, } \\
\text { Tribunus militum a/ab populo }\end{array}$ & Etruský & $\begin{array}{l}27 \text { p.n.l. - } 14 \text { n.I. (Campbell 2015, 155); } \\
20 \text { p.n.I. - } 20 \text { n.l. (Kockel 1983, 53) }\end{array}$ \\
\hline $\begin{array}{l}\text { Verejná kňažka kultu Venuši/Ceres } \\
\text { (Will 1979, 37) }\end{array}$ & $\begin{array}{l}\text { Kampánsky (oskánsko- } \\
\text { samnitstký) }\end{array}$ & $\begin{array}{l}27 \text { p.n.l. - } 14 \text { n.l. (Campbell 2015, } \\
\text { 158); } 30 \text { - } 40 \text { n.l. (Borelli 1937, 17) }\end{array}$ \\
\hline $\begin{array}{l}\text { Arellia Tertulla - neznámy; } \\
\text { Veius Frontus - Aedil } \\
\text { (v čase výstavby), Duovir } \\
\text { a Quinquennalis počas života } \\
\text { (Franklin 2004, 26) }\end{array}$ & $\begin{array}{l}\text { Arellia Tertulla - Kampánsky } \\
\text { (oskánsko-samnitstký); Veius } \\
\text { Frontus - etruský }\end{array}$ & $\begin{array}{l}14 \text { n.I. (Campbell 2015, 204); } \\
16 \text { n.I. (Franklin 2004, 26); } \\
26 \text { n.I. (Scott 1989, 89) }\end{array}$ \\
\hline $\begin{array}{l}\text { Aesquillia Polla - neznámy; } \\
\text { Numerius Herennius Celsus - } \\
\text { Praefekt fabrus, Duovir }\end{array}$ & $\begin{array}{l}\text { Aesquillia Polla - neznámy; } \\
\text { Numerius Herennius Celsus - } \\
\text { Kampánsky (oskánsko-samnitský) }\end{array}$ & $\begin{array}{l}14 \text { - } 54 \text { n.I. (Cooley - Cooley 2004, } \\
\text { 139; James - Dillon 2015, 410); } \\
62 \text { - } 79 \text { n.I. (Campbell 2015, 209) }\end{array}$ \\
\hline $\begin{array}{l}\text { Kňaz/Kňažka verejného kultu Ceres } \\
\text { (Kay - Alapont - Albiach 2018, 416) } \\
\text { alebo Dionýza } \\
\text { (Borelli 1937, 25) }\end{array}$ & Neznámy & $\begin{array}{l}\text { 70te roky n.I. (Campbell 2015, 210); } \\
\text { Nedokončená (Richardson 1988, 365) }\end{array}$ \\
\hline Neznámy & Neznámy & $\begin{array}{l}\text { Nedokončená/porušená } 62 \text { - } 79 \text { n.l. } \\
\text { (Richardson 1988, 254) }\end{array}$ \\
\hline $\begin{array}{l}\text { kňažka kultu Venuši (Will 1979, 40) } \\
\text { alebo Ceres (Gordon 1927, 176) }\end{array}$ & Grécky & $\begin{array}{l}\text { 1-10 n.l. (Scott 2019, 91); 1-30 n.l. } \\
\text { (Campbell 2015, 259) }\end{array}$ \\
\hline $\begin{array}{l}\text { Duovir, Quinquennalis, Tribunus } \\
\text { militum a/ab populo }\end{array}$ & Latinský & $\begin{array}{l}27 \text { p.n.l. - 1/2 n. I. } \\
\text { (Campbell 2015, 300) }\end{array}$ \\
\hline Duovir & Neznámy & $\begin{array}{l}27 \text { p.n.l. - } 14 \text { n. I. } \\
\text { (Campbell 2015, 302) }\end{array}$ \\
\hline Neznáma & Neznámy & Neznáma \\
\hline
\end{tabular}


nekropole bol skúmaný predovšetkým priestor za scholami Marca Tullia a Marca Alleia Minia. Tieto výskumy z prelomu 19. a 20. storočia však neboli úspešné a miesta pohrebných urien tak zostali otázne (Mau 1890, 281). Nakoniec bol priestor za oboma zmienenými scholami interpretovaný ako funerálne záhrady (Spano 1910, 569). S ohladom na skutočnost neexistencie pohrebov v blízkosti jednotlivých schol je diskutabilné, či by tieto štruktúry mali byt nad’alej označované ako hrobky a či by termín komemoratívnych pamätníkov nebol vhodnejší.

\subsection{Verejné funkcie a stavebná činnost' osôb v kontexte pompejských schol}

Na základe dochovaných inskripcií je zrejmé, že výstavba štruktúr typu schola bola spätá s najvyššou pompejskou aristokraciou, čo dokladajú i tituly a verejné funkcie, ktorými konkrétne osoby disponovali. V rámci schol je funkcia aedila spomenutá iba raz, a to v prípade Veia Fronta, ktorý dal postavit a dedikoval svojej manželke Arellii Tertulle ${ }^{12}$ scholu za Vesuijskou bránou. V prípade zmieneného titulu Veia Fronta je ale známe, že počas svojho života vykonával funkciu duumvira a s najväčšou pravdepodobnostou i úrad quinquennala. Ako uvádza Franklin, v prípade, že by táto schola bola postavená v období jeho duumvirátu či neskôr, tieto tituly by boli na tejto schole určite zmienené. $\mathrm{V}$ tomto prípade teda uvažuje nad tým, či Veius Frontus svoju manželku nepochovával v mladom veku, kedy ešte zastupoval len úrad aedila (Franklin 2004, 26). Najčastejšou verejnou funkciou, ktorá býva zmieňovaná na dedikačných nápisoch schol, je funkcia duumvira. Túto verejnú funkciu zastávali L. Sepunius Sandilianus a M. Herennius Epidianus, ktorí sa zaslúžili o výstavbu scholy na Trojuholníkovom fóre ${ }^{13}$ (Keegan - Sears - Laurence 2013, 95), Numerius Herennius Celsus, ktorý sa zaslúžil o výstavbu scholy pre svoju manžel- ku Aesquilliu Pollu ${ }^{14}$ za Nolskou bránou (Spano 1910, 390), a Marcus Alleius Minius ${ }^{15}$ (Campbell, 2015, 302), ktorého schola sa nachádza za Stabijskou bránou. Úrad najvyššieho predstavitela verejnej a úradnej moci v Pompejách, a teda úrad quinquennala, zastávali Aulus Veius ${ }^{16}$ (Campbell 2015, 155), ktorého schola sa nachádza za Herkulánejskou bránou, a Marcus Tullius, ktorého schola je umiestnená za Stabijskou bránou. I ked' je dedikačný nápis ${ }^{17}$ na tejto schole skratkovitý, tituly Marca Tullia sú známe z d'alšieho dedikačného nápisu ${ }^{18}$, ktorý sa našiel v blízkosti chrámu Fortuny Augusty postaveného na fóre. V prípade Aula Veia a Marca Tullia však treba spomenút i čestný titul, udelovaný v období vlády Augusta, a to titul Tribunus militum ab populo, ktorým sa v Pompejách pýšilo iba šest̉ osôb (Kockel 1983, 53). V prípade Aula Veia je otázne, čím sa o tento titul zaslúžil, keď̌e $\mathrm{v}$ prípade jeho osoby a spomenutých titulov na dedikačnom nápise na tejto schole nie je známa jeho d’alšia stavebná činnosṫ. Opakom je však osoba Marca Tullia. Nález jeho scholy nie je v kontexte jeho stavebnej činnosti v Pompejách jediný, pretože sa zaslúžil ešte o výstavbu zmieneného chrámu Fortuny Augusty na fóre (Zanker 1998, 83). Stavebná činnosṫ osôb spätých so scholami je popísaná v nasledujúcom odstavci. Predchádzajúce riadky sa venujú verejným úradníckym funkciám v rámci Pompejí, ktoré v rímskej spoločnosti mohli zastupovat iba osoby mužského pohlavia. Problematika schol je ale spojená i so ženami. Ide konkrétne o Arelliu Tertullu (schola za Vesuvijskou bránou), Aesquilliu Pollu (schola za Nolskou bránou), Mamiu (schola za Herkulánejskou bránou) a Eumachiu (hrobka za Nocerijskou bránou). I ked' ženy z aristokratických rodov nemohli v antike zastávat úradnícke funkcie, verejnú činnosṫ vykonávali predovšetkým ako kňažky kultov či sa podielali na výstavbe a zvelad’ovaní budov určených pre širokú verejnost' (James - Dillon 2015, 401). V prípade Arellie Tertully a Aesquillie Polly nie je zmienená funkcia 
kňažky kultu či prípadná stavebná činnost̉ známa. V tomto prípade ide predovšetkým o manželky vysoko postavených úradníkov. Je teda otázne, či scholy dedikované zmieneným dámam nepredstavovali iba komemoratívne pamätníky na oslavu a vyzdvihnutie verejných funkcií ich manželov ${ }^{19}$, ktorí im tieto scholy dali postavit a následne im ich dedikovali. Prípad Mamie už je ale odlišnejší. Práve dedikačný nápis ${ }^{20}$ umiestnený na operadle jej scholy za Herkulánejskou bránou dokladá, že išlo o kňažku verejného kultu, bohužial však bez bližšej špecifikácie. Podla Warda išlo o funkciu, do ktorej musela byt prijatá až po odsúhlasení verejným hlasovaním (Ward 1998, 320), a Willová následne dopĺňa, že s najväčšou pravdepodobnostou slúžila kultu bohyne Venuše alebo Ceres (Will 1979, 37). Úplne rovnaký názor prevláda i v prípade osoby Eumachie, podla ktorého bola Eumachia verejná kňažka kultu bohyne Venuše (Will 1979, 40) alebo Ceres (Gordon 1927, 176). Posledným prípadom, v ktorom bádatelia premýšlajú o výkone verejného kultu, je osoba, ktorá stojí za výstavbou alebo ktorej bola dedikovaná neznáma schola za Nolskou bránou. Na tejto schole sa však bohužial nenachádza žiaden dedikačný nápis, ktorý by udával bližšie informácie o tejto osobe (Kay - Alapont - Albiach 2018, 416). Na základe dochovanej výzdoby, ktorá zobrazuje cistu mysticu lemovanú zväzkami obilia, ktorá sa nachádzala na oltári, sa bádatelia domnievajú, že táto schola bola postavená pre ženu, pravdepodobne verejnú kňažku kultu bohyne Ceres (Kay - Alapont - Albiach 2018, 416). Borelliová na druhú stranu argumentuje, že cista mystica býva spojovaná i s kultom Demeter a Dionýza. Podla nej sa osoba, ktorej táto schola mala byt dedikovaná, zúčastňovala Dionýzových mystérií a táto štruktúra mohla byt postavená ešte počas života tejto osoby (Borelli 1937, 25). Cista mystica ako ikonorafický motív nebol v antike nijakou raritou. Túto nádobu, či prútený kôš je vo funerálnom kontexte možné vidiet na sarkofágoch, ktoré sú opät späté s postavou Dionýza, či vo forme keramických nádob a urien, ktoré sú nachádzané na území celého impéria. Ďalším miestom, na ktorých je možné nájst' ikonografiu cisty sú mince označované ako cistophoroi a v nemalom počte sa tento motív nachádza i na striebornej toreutike (Jilek 2007, 82). Samotné vysvetlenie tohto motívu je predmetom diskusie a bádatelia ju spojujú predovšetkým s kultom Dionýza a jeho mystériami, ktorých súčastou bolo pitie vína s odkazom na mytologický príbeh o Dionýzovom zabití a znovuzrodení (Jilek 2007, 85). Vzhladom na chýbajúcu dedikáciu na schole s motívom tejto cisty však stále zostáva otázne, kto alebo komu táto stavba bola postavená, rovnako ako i to či táto konkrétna schola mohla v zmienených mystériách zohrávat špecifickú úlohu.

$\mathrm{V}$ prípade problematiky štruktúr typu schola je nutné zmienit i stavebnú činnost̉ v rámci Pompejí, o ktorú sa zaslúžili vybrané osoby späté s výstavbou schol. Konkrétne ide o osobu kňažiek Mamie a Eumachie, duumvirov L. Sepunia Sandiliana a M. Herennia Epidiania a quinquennala Marca Tullia. Je podivuhodné, že stavebná činnosṫ zmienených osôb je sústredená v oblasti pompejského fóra a ich stavby sú späté prevažne s cisárskym kultom. Na jednu stranu by výnimkou mohla byt stavba horológia na fóre pred chrámom Apolóna, o ktorú sa zaslúžili duumviri L. Sepunius Sandilianus a $M$. Herennius Epidianus, ako dokladá dochovaná inskripcia ${ }^{21}$. Výstavba tohto horológia mohla byt ukážkou vhodného daru bohovi Apolónovi, ktorý býva spájaný i so slnečnými božstvami Helia či Sola (Wilkinson 2017, 92). Na opačnú stranu bol však kult Apolóna v období Augustovej vlády spájaný s jeho osobou, ked’že si ho Augustus vyvolil za osobné ochranné božstvo. Je teda otázne, či i výstavba tohto horológia nemohla predstavovat nepriamu podporu cisárskej rodiny. Podl'a všetkého ale bola výstavba scholy s horológiom na Trojuholníkovom fóre 
a výstavba horológia na fóre prejav euergetismu či dobrej vôle v prospech širokej verejnosti (Keegan - Sears - Laurence 2013, 94-95). Ďalšou verejnou stavbou v spojitosti so scholami je oltár Genius Augusti, ktorý dala na vlastné náklady postavit kňažka Mamia (Cooley - Cooley 2013, 138). Išlo o stavbu štvorcového pôdorysu s centrálnym dvorom, uprostred ktorého sa nachádzal oltár a v zadnej časti bol navyše umiestnený malý italický frontálny chrám (Dobbins 2008, 163). Výstavba tejto štruktúry býva datovaná do rozmedzia rokov 7-2 p.n.l. (Nissen 1877, 272). Táto stavba dostala svoje pomenovanie na základe dedikačného nápi$\mathrm{su}^{22}$, avšak skutočná dedikácia tohto komplexu zostáva neznáma. Na jednej strane prevláda argument, že išlo o chrám postavený za účelom uctievania kultu cisárskej rodiny. Proti tomuto tvrdeniu ale vyvstávajú pochybnosti, pretože v dobe prelomu letopočtu nebolo zvykom stavat chrámy dedikované cisárskemu kultu na území Talianska. Stavba takýchto chrámov síce prebiehala, ale výlučne na území provincií na upevnenie postavenia cisárskej rodiny, a to vždy v spojení s d’alším božstvom (Fishwick 1995, 19). Podla Dobbinsa bol teda tento komplex postavený skôr za účelom uctievania genia kolónie Augustani (Dobbins 2008, 164). V tesnej blízkosti tohto komplexu stojí tzv. Eumachina budova, ktorá sa zaslúžila o jej výstavbu (Mau 1904, 110). Dedikácia ${ }^{23}$ nájdená v dvoch exemplároch dokladá, že Eumachia dala tento komplex postavit na vlastné náklady a dedikovala ju Concordii Auguste a Pietas (Dobbins 2008, 165). V postranných kolonádach tejto budovy sa nachádzali sochy hrdinov rímskej histórie, ako Aenea a Romula, spolu so sochami predstavitel'ov významných osobností, medzi inými aj Caesara a Augusta (Will 1979, 38). Ústredná socha bohyne Concordie Augusty s rohom hojnosti sa nachádzala v najväčšom výklenku v zadnej časti komplexu (Richardson 1988, 198) a predlohou tejto sochy mala byt Livia (Will
1979, 39). Ned’aleko tejto sochy bola nájdená i socha zobrazujúca samotnú Eumachiu, ktorú jej dali postavit takzvaní fulloni ${ }^{24}$ (Campbell 2015, 116), ako dokladá dedikačný nápis ${ }^{25}$. Predmetom diskusie je účel a datácia výstavby tejto budovy. Z hladiska funkčnosti ju bádatelia označujú ako miesto určené na spracovanie vlny (Dobbins 2008, 167) alebo látok všeobecne (Mau 1904, 112). Mohlo íst́ však aj o miesto, kde sa uskutočňoval obchod so zmienenými látkami, ale i inými obchodnými komoditami (Richardson 1988, 198). Datácia výstavby tejto budovy býva udávaná bud' do obdobia vlády Augusta, konkrétne do roku 2-3 n.l. na základe podobnosti s porticom, ktorý sa nachádzal na Augustovom fóre v Ríme (Richardson 1988, 195-196), alebo do obdobia vlády cisára Tiberia (Mau 1904, 111). Posledná stavebná činnost’ na fóre v kontexte pompejských schol je chrám Fortuny Augusty, ktorý dal na vlastné náklady postavit Marcus Tullius (Ling 2008, 122). Typický italický frontálny chrám s jedinou cellou ( $\mathrm{Za}$ nker 1998, 83) bol dedikovaný kultu Augusta a bohyne Fortuny (Westfall 2008, 136). V rámci Pompejí ide o prvý a ojedinelý chrám dedikovaný cisárskemu kultu (Ling 2008, 122). Mimo tohto chrámu je s osobou Marca Tullia spojený i nález jazdeckej sochy muža odetého v tóge, ktorá sa našla v severnej časti fóra v blízkosti zmieneného chrámu Fortuny Augusty (Zanker 1998, 84). Vyvstáva však otázka o totožnosti vyobrazenej osoby. Podla Welchovej táto socha nápadne pripomína osobu cisára Tiberia, avšak sama dodáva, že tento fakt môže byt spôsobený dobovou štylizáciou portrétov. Vzhladom na fakt, že táto socha zobrazuje muža v strednom veku, Welchová dodáva, že môže íst' o zobrazenie samotného Marca Tullia (Welch 2008, 554). V prípade, že táto socha mohla zobrazovat Marca Tullia, je však otázne, či si dal túto sochu postavit sám na upevnenie svojej moci v rámci mesta, alebo mu túto sochu dali postavit post mortem na jeho počest'. 


\subsection{Datovanie schol}

Ako je už naznačené vyššie, jedným z d'alších problematických aspektov v spojitosti s pompejskými scholami je ich datovanie. Najbežnejšie používaná datácia všeobecne pre všetky štruktúry tohto typu je udávaná do obdobia vlády Augusta (27 p.n.1. - 14 n.1.) a Tiberia (14 n.1. - 37 n.1.) (Campbell 2015, 49). Ako je však možné vidiet v priloženej tabul'ke (Tab. 1), i v tomto prípade sa názory bádatel’ov rozchádzajú. V kontexte datovania pompejských schol je však možné tieto štruktúry rozdelit do dvoch kategórií, a to na tie, ktoré skutočne spadajú do časového rámca vlády Augusta a Tiberia, a potom na tie, o ktorých sa predpokladá, že mohli byt postavené až v neskoršom období počas vlády Fláviouskej dynastie.

Do prvej kategórie spadajú nasledovné scholy. Prvou je schola na Trojuholníkovom fóre, ktorú dali postavit duumviri L. Sepunius Sandilianus a M. Herennius Epidianus. Podla Richardsona by táto schola mohla byt datačne najstaršia a jej výstavbu časovo udáva do obdobia prechodu od republiky k cisárstvu, konkrétne do rozpätia rokov 30-20 p.n.l. Podla neho výstavba tejto scholy prebiehala paralelne s výstavbou sochy Marcella, Augustovho synovca, ktorá sa taktiež nachádza na Trojuholníkovom fóre $\mathrm{v}$ blízkosti tejto scholy (Richardson 1988, 82). Ďalším exemplárom spadajúcim do tohto časového rámca je schola Aula Veia za Herkulánejskou bránou. Datácia tejto scholy býva odvodzovaná od titulu tribuna militia a/ab popula, príznačného čisto pre dobu Augustovej vlády. Konkrétne datovanie tejto scholy je problematické vzhladom na nedostatok informácií ohladom osoby Aula Veia. Zatial čo Campbellová datuje túto scholu tradične do rámca Augustovej vlády (27 p.n.l. - 14 n.1.) (Campbell 2015, 155), Kockel toto datovanie udáva medzi roky 20 p.n.l. - 20 n.l. Podla neho smrt̉ Aula Veia nastala až po Tiberiovom nástupe na trón (Kockel 1983, 53). Do podobného časo- vého rámca býva datovaná i schola Marca Tullia, ktorý rovnako ako Aulus Veius disponoval titulom tribuna militia a/ab popula. Podla Campbellovej je túto scholu možné datovat' do rozpätia rokov 27 p.n.1. - 1/2 n.1. (Campbell 2015, 300). Protiargument k tejto datácií udáva Franklin na základe výstavby chrámu Fortuny Augusty, ktorý dal Marcus Tullius postavit'. Výstavba tohto chrámu je udávaná do roku 3 n.l. a z dochovaných inskripcií je známe, že Marcus Tullius v dobe dokončenia tohto chrámu ešte žil (Franklin 2001, 29). Samozrejme možnost', že táto schola bola postavená ešte počas jeho života, je rovnako pravdepodobná. Ďalšou scholou, ktorá býva datovaná do tohto obdobia, je schola Mamie za Herkulánejskou bránou. Campbellová ju už tradične datuje do rokov 27 p.n.l - 14 n.l. (Campbell 2015, 158), podobne i Kockel ju datuje do obdobia vlády Augusta a Tiberia (Kockel 1983, 58). Avšak podla Borelliovej bola táto schola postavená až v rokoch 30-40 n.l. Odvodzuje ju od datácie výstavby oltáru Genia Augusty, ktorá bola dokončená v rokoch 7-2 p.n.l. Podla nej bola Mamia v tomto období na vrchole života a jej úmrtie nastalo až po smrti Augusta (Borelli 1937, 17). K podobnému názoru na základe rovnakého argumentu, aký predkladá Borelliová, sa prikláňa i Willová, ale výstavbu tejto scholy udáva do prvej štvrtiny 1. storočia n.l. (Will 1979, 37). Do obdobia prvých rokov n.l. spadá i hrobka Eumachie (Scott 2013, 91), podla Campbellovej konkrétne do rozpätia rokov 1-30 n.l. (Campbell 2015, 259). Toto datovanie znovu odvodzuje od doby výstavby Eumachinej budovy na fóre, ktorá bola podla nej dokončená v roku 7 n.l., v období vrcholu života Eumachie (Campbell 2015, 116-117). Posledná z pompejských schol, ktorá býva udávaná do časového rámca Augustovej vlády, je schola Marca Alleia Minia za Stabijskou bránou. V tomto prípade je dedikačný nápis umiestnený na schole jediný doklad života M. Alleia Minia, preto je bližšia datácia nemožná. Približné datovanie tejto scholy je odvodené 
na základe jej štylistického prevedenia, ktoré je nápadne podobné so scholami Aula Veia a Mamie za Herkulánejskou bránou (Campbell 2015, 302; Emmerson 2010, 78).

Ďalšou scholou v poradí, ktorá je problematická v otázke datovania, je schola dedikovaná Arellii Tertulle za Vesuvijskou bránou. Podla epigrafického nápisu bola táto schola postavená až po smrti Arellie jej manželom Veiom Frontom, ktorá podla Scotta nastala okolo roku 26 n.l. (Scott 2013, 89). Franklin však s týmto dátumom nesúhlasí a dobu jej smrti udáva o dekádu skôr. Tento argument opiera o dochované volebné nápisy Veia Fronta, ktorý v roku 26 n.l. už podla všetkého úradoval vo funkcií quinquennala, minimálne mal za sebou už úrad duumvira. Na tejto schole je však v spojitosti s Veiom Frontom zmienený iba titul aedila. Ak by bola táto schola postavená v tomto roku, jeho d’alšie tituly by boli na dedikačnom nápise pravdepodobne zmienené (Franklin 2004, 26). Na základe architektonického prídavku vo forme stĺpu argumentuje Spano protichodne a podla jeho názoru sú scholy Arellie Tertully a Aesquillie Polly datačne mladšie. Podla neho je prítomnost' stĺpu snahou o monumentálnejšie prevedenie štruktúry, ktoré je charakteristické až pre obdobie po vláde Augusta a to konkrétne pre obdobie vlády Fláviovcov (Spano 1910, 406). Práve na základe prítomnosti stĺpu býva preto schola Aesquillie Polly za Nolskou bránou datovaná do obdobia vlády dynastie Fláviovcov (Campbell 2015, 209), pričom podla Richardsona bola výstavba tejto scholy dokončená až po ničivom zemetrasení v roku 62 n.l. (Richardson 1988, 365). Do rovnakého obdobia býva datovaná i schola bez dedikácie, ktorá sa nachádza v tesnej blízkosti scholy Aesquillie Polly, taktiež za Nolskou bránou. Podla Richardsona nebola táto schola nikdy dokončená, čo dokládá i čerstvé rytie výzdoby oltáru a nedokončený chodník (Richardson 1988, 365). Túto teóriu potvrdzuje i najnovší výskum Britskej školy v Ríme, ktorý na základe GPR analýzy doložil, že južná čast’ bázy tejto scholy nebola dokončená alebo mohla byt’ v procese rekonštrukcie po silnom zemetrasení $\mathrm{v}$ roku 62 n.l. (Kay - Alapont - Albiach 2018, 416). Na druhú stranu neexistuje doklad, že by bola prilahlá schola Aesquillie Polly výrazne poškodená, čo môže znamenat', že výstavba tohto typu štruktúr nespadá výhradne do raného obdobia vlády julsko-klaudiovskej dynastie. Je teda možné skôr tvrdit, že výstavba štruktúr typu schola začína v Pompejách v období prerodu republiky v principát a že táto výstavba pokračovala až do osudného dňa, kedy Pompeje pochoval Vezuv.

\subsection{Scholy v kontexte kultúrneho pô- vodu osôb, ktorým boli dedikované alebo sa o ich výstavbu zaslúžili}

V tejto podkapitole je v rámci možnosti v náväznosti na prvú čast’ práce ohladom kultúrneho osídlovania Pompejí popísaný kultúrny pôvod osôb, ktoré sú spojené s výstavbou schol. Popis osôb je rozdelený na základe príslušnosti ku gréckemu, etruskému, kampánskemu či latinskému kultúrnemu pôvodu. Bohužial žiadny z dochovaných nápisov, či už priamo na scholách alebo celoplošne v Pompejách nezmieňujú konkrétny kultúrny pôvod daných osôb. Táto čast̉ preto vychádza primárne zo sekundárnej literatúry novodobých bádatelov a $\mathrm{z}$ moderných prosopografických analýz. V kontexte pompejských schol je jediným potomkom gréckych kolonistov Eumachia. Rod Eumachie patril v období výstavby Eumachinej hrobky k starému kampánskemu rodu gréckeho pôvodu (Castrén 1975, 165), ktorý na územie Neapolského zálivu prišiel v 6. storočí p.n.l. (Will 1979, 37). Medzi osoby s etruským pôvodom patril Aulus Veius a Veius Frontus. Prítomnost' rodu Veii v Pompejách siaha do obdobia republiky (Franklin 2004, 21) a podla Maiuriho cognomen Veii odkazuje na rodinu etruského gentilicia, ktorá až do obdo- 
bia romanizácie Etrúrie ovládala etruské mesto Veje (Maiuri 1960, 309). Do skupiny potomkov s latinským kultúrnym pôvodom patrí Marcus Tullius. Podla Reinfjorda pochádzala rodina Tullii priamo z Ríma a do Pompejí sa tento rod dostal po občianskej vojne v roku 80 p.n.l. (Reinfjord 2011, 18). Po dobytí Pompejí a usadení veteránov sa tu rod Tullii zaradil k pompejskej aristokracií a príslušníci tohto rodu tu krátko nato začali vykonávat úradnícke funkcie (Wilkinson 2017, 43). Najväčšie zastúpenie v kontexte pompejských schol majú osoby s originálnym kampánskym kultúrnym pôvodom. Do tejto skupiny patrí oskánsky rod Herenii (Adams 2003, 124), ktorého potomkami bol $M$. Herennius Epidianus a N. Herennius Celsus. Ďalšou osobou oskánskeho pôvodu mala byt kňažka Mamia. Usudzuje sa, že jej rodina ovládala Pompeje a Herkuláneum až do dobytia Pompejí v roku 80 p.n.l. (Will 1979, 37), avšak i potom si staré oskánsko-samntistké rodiny ponechávajú svoju moc a nad’alej vykonávajú verejné úradnícke funkcie (Descoeudres 2008, 16). Poslednou predstavitel'kou v spojitosti so scholami, ktorej pôvod je udávaný ako kampánsky, je Arellia Tertulla z rodu Arelliov (Nonnis - Ricci 1999, 44). Nevyjasnený kultúrny pôvod tak zostáva v spojitosti s osobou L. Sepunia Sandiliana, Aesquillie Polly a M. Alleia Minia.

\section{Vybrané príklady exedier z obdobia helenizmu vo východnom Stredomorí}

Ako predlohou pompejských schol z hladiska formy týchto štruktúr bývajú udávané polkruhové alebo rektangulárne štruktúry známe ako exedry z obdobia neskorej klasiky, helenizmu a neskôr i doby rímskej, ktoré sa vo vel'kom počte nachádzajú vo východnom Stredomorí (Obr. 11). Tieto exedry vyhotovené prevažne z monolitu alebo z niekolkých kamenných blokov, sú tvarom a ich umiestnením na vyvýšenej báze či pódiu totožné s pompejskými scholami. Ich výskyt na jednotlivých lokalitách je ale na rozdiel od Pompejí nielen v urbánnom a funerálnom priestore ale i v rámci posvätných okrskov. Ako exemplár môže poslúžit napríklad exedra z 3. storočia p.n.l. v Labraunde, ktorá sa nachádzala v blízkosti chrámu Dia (Hellström 2007, 106107). Príkladom využívania exedier v rozdielnom kontexte na nekropolách je lokalita Patara na území antickej Lýkie (Aktaş 2008, 235). Na nej boli nájdene monolitické exedry v tvare polkruhu s pohrebnou urnou vytesanou taktiež z kameňa, ktorá bola umiestnená nad operadlom (Obr. 12) (Aktaş 2008, 244). Výskyt exedier na nekropolách však nie je obmedzený iba na funerálny kontext. Takéto exedry sa tu vyskytujú i na hlavných cestách, ktoré lemovali nekropole. Ovela častejší je výskyt exedier určených na odpočinok v rámci urbánneho alebo sakrálneho priestoru v mestách a v posvätných okrskoch. Najpočetnejšie zastúpenie exedier býva v rámci miest, kde sa tieto štruktúry nachádzajú prevažne v okolí agory a pozdĺž ciest, ktoré smerovali na akropolu a agoru. $\mathrm{V}$ rámci posvätných okrskov je tieto exedry možné lokalizovat opät pozdĺž procesných ciest (Dillon 2010, 32). Tieto exedry tu bývali stavané nielen na popud konkrétnej polis, ale i súkromnými osobami, ktoré väčšinou, rovnako ako i v prípade Pompejí, patrili k vládnucej elite $\mathrm{v}$ danom meste (Kristensen 2018, 92). V súvislosti s výstavbou exedier, ktoré boli financované súkromnými osobami, je potrebné zmienit častý fenomén, ktorý sa v Pompejách neobjavuje. Ide o sochy umiestnené na operadle exedier zobrazujúce členov rodiny, ktorí sa zaslúžili o ich výstavbu. Tieto sochy bývali zhotovované predovšetkým z bronzu a kameňa a okrem heroizovaného zobrazenia danej rodiny sa tu nachádzali i mytologické scenérie (Neumann 2011, 309). V období helenizmu však sú stavané i exedry na popud králov za propagandistickým účelom. Príkladom takýchto 


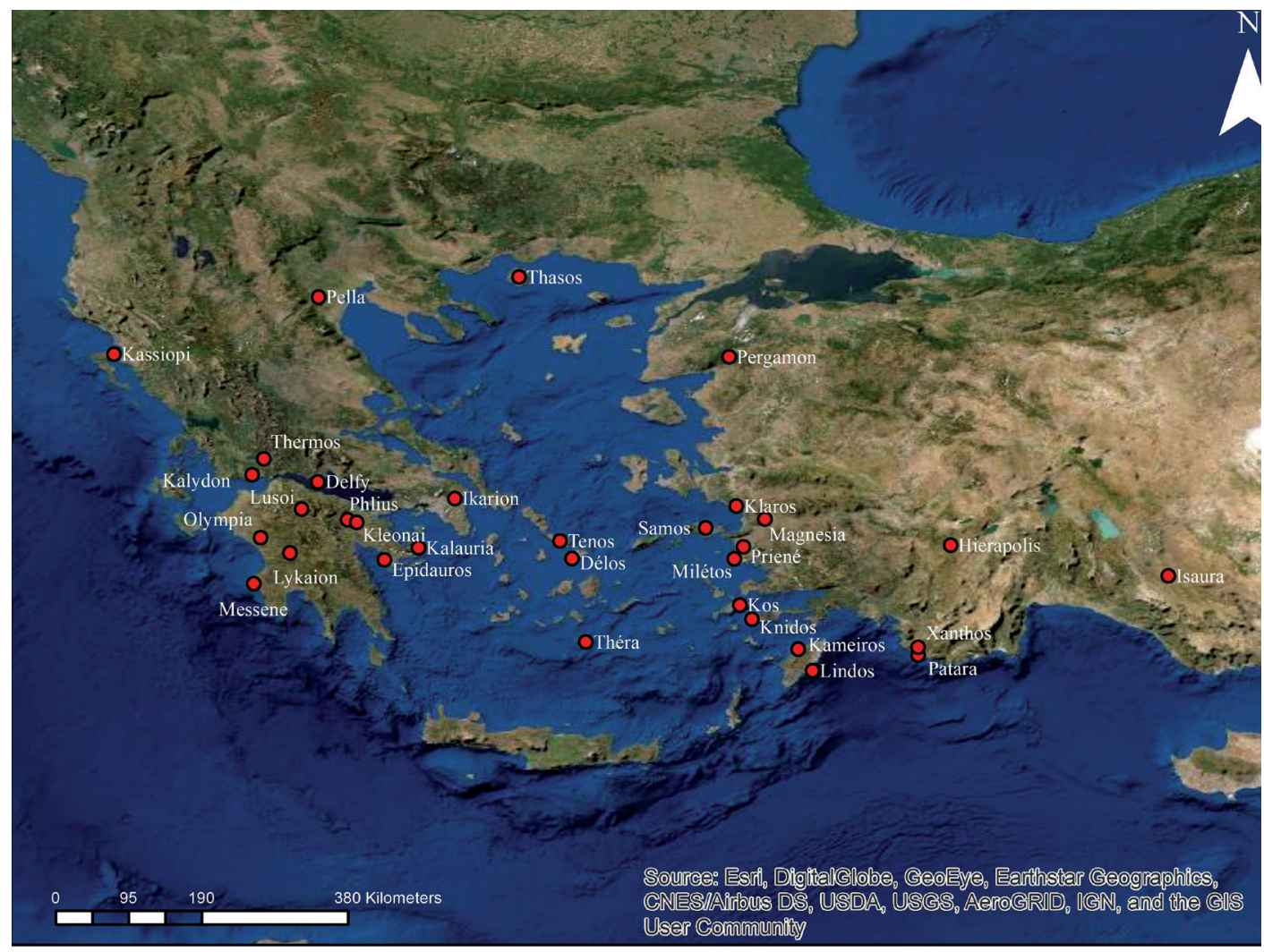

Obr. 11: Grafické znázornenie výskytu exedier v období helénizmu a doby rímskej vo východnom Stredomorí.

Fig. 11: Graphic representation of the occurrence of exedrae in the Hellenistic and Roman periods in the Eastern Mediterranean.

exedier je exedra Atalla I., ktorý dal po vítazstve nad Galmi postavit exedru na Apolónovom okrsku v Delfách (Stillwell 2017, 265), alebo exedra Atalla II., ktorý ju dal postavit’ v blízkosti Pergamonského oltáru po nástupe na trón v roku 159 p.n.l. (Borelli 1937, 37-38). Okrem zmienených exedier $\mathrm{z}$ obdobia helenizmu sa vo východnom Stredomorí nachádzajú i exedry z doby rímskej, ktoré tu bývali stavané taktiež za propagandistickým účelom. Stavba týchto exedier je spojená napríklad s postavou cisára Trajána, ktorý dáva v Pergamone postavit chrám zvaný Trajaneum a v jeho tesnej blízkosti dve exedry určené na odpočinok (Nohlen 2011, 162). Jeho príklad nasleduje i cisár Hadrián, ktorý sa v roku 125 n.l. zaslúžil o výstavbu tzv. Exedry Hadrianei na Apolónovom okrsku v Delfách (Swain 1991, 322).

\section{Diskusia}

Vzhladom na nemalý výskyt exedier určených na odpočinok vo východnom Stredomorí je zrejmé, že prebratie tohto architektonického motívu v Pompejách prišlo z oblasti východu ríše. Postupná helenizácia Rímskeho impéria je mimo iného dobre viditelná i v architektonickom usporiadaní Kapitolu a Palatinu v Ríme, ktorý nápadne pripomína terasovitý plán helenistického Pergamonu 


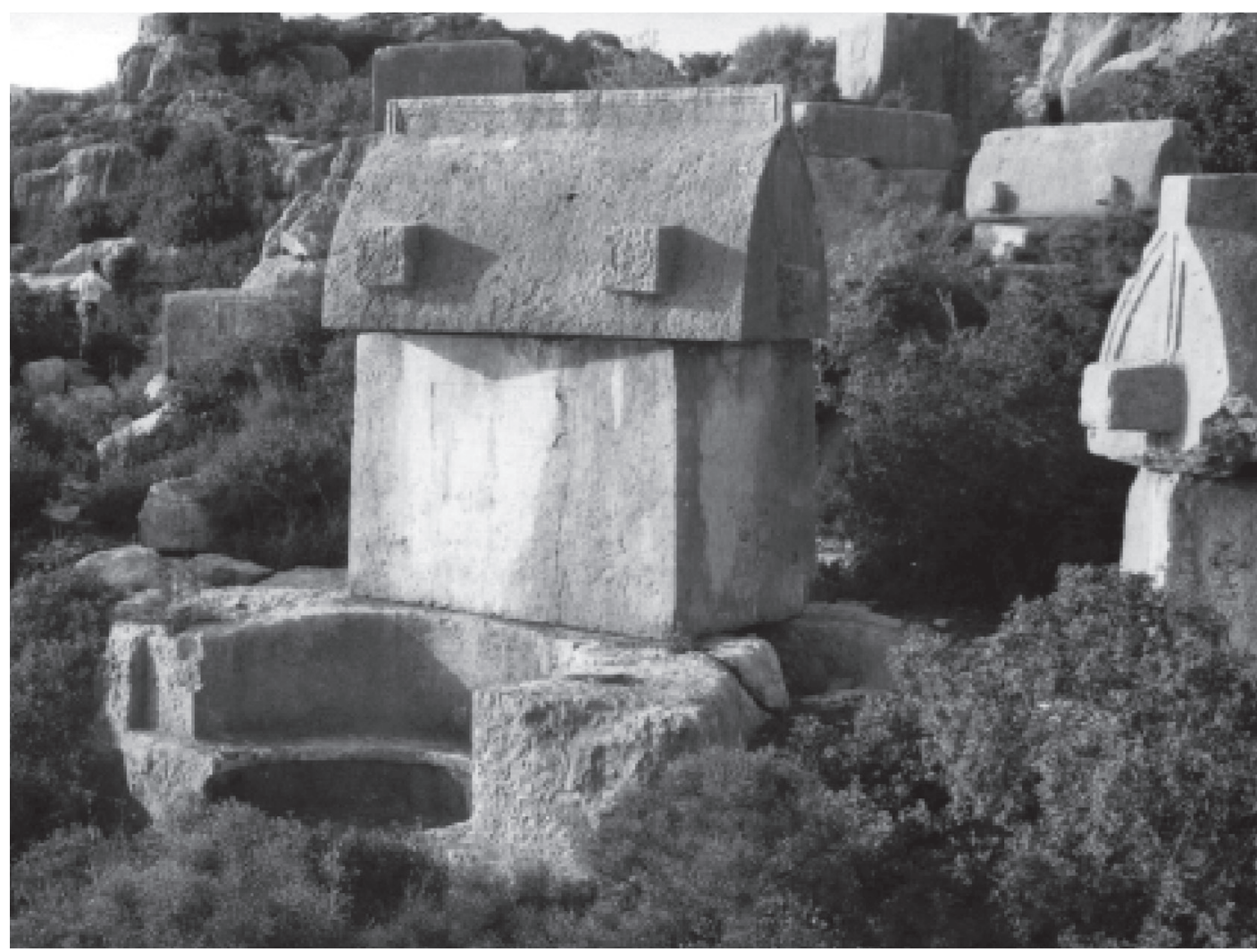

Obr. 12: Exedra s pohrebnou urnou na nekropole v Teimusse. Zdroj: Aktaş 2008.

Fig. 12: Exedra with a cinerary urn in the necropolis of Teimussa (Aktaş 2008).

(Viscogliosi 2019, 92). Inšpiráciu pergamskou architektúrou alebo helenistickou architektúrou všeobecne je možné vidiet i na príklade pompejských schol. Je však podivuhodné, že scholy začínajú byt’ v Pompejách stavané až v augustovskom období, a že sa tu táto myšlienka neuchytila už v predchádzajúcom období počas republiky. Nízky počet schol v Pompejách je rovnako otázny vzhladom na fakt, že v helenistických mestách vo východnom Stredomorí bývajú tieto exedry stavané vo vel'kom počte $\mathrm{v}$ rámci jedného mesta či posvätného okrsku, väčšinou $\mathrm{v}$ počte desiatok exedier. Je zrejmé, že pompejské scholy slúžili predovšetkým ako komemoratívne stavby, ktoré oslavovali jedincov, ktorým boli dedikované alebo sa o ich výstavbu zaslúžili. Komemorácia konkrétnych osôb ale nemohla byt daná iba na základe ich stavebnej činnosti v meste, ked’že z jedenástich osôb, ktoré sú spojené so scholami, je iba u štyroch doložená stavebná činnost'. Až do prípadných nálezov, ktoré by túto otázku v budúcnosti zodpovedali tak zostáva otázne, čím sa zvyšné osoby zaslúžili o to, aby im z poverenia rady decuriones boli tieto scholy postavené. S ohl'adom na rodové rozloženie je zrejmé, že výstavba schol nebola vyčlenená len pre mužských členov pompejskej aristokracie, ale že problematika týchto štruktúr sa týka i žien. V prípade scholy Arellie 
Tertully a Aesquillie Polly, je otázne, či nemôže íst predovšetkým o komemoratívny pamätník, ktorý oslavuje život a funkcie ich manželov, Veia Fronta a N. Herennia Celsa, alebo či sa svojím spoločenským postavením či verejnou činnostou sami zaslúžili o výstavbu týchto štruktúr z poverenia rady decuriones. Otázka ale vyvstáva pri samotnom uložení ostatkov spomínaných osôb. Je možné sa hypoteticky domnievat, že tieto ostatky mohli byt’ uložené v hrobkách jednotlivých rodov, alebo že tieto osoby patrili do konkrétneho funerálneho spolku. Členstvo vo funerálnych spolkoch však býva spájané s menej majetnými občanmi Rímskej ríše. Otázkou teda je, kde sú dotyčné osoby spojené so scholami vôbec pochované, ked’že dodnes nebol nájdený jediný hrob - s výnimkou monumentálnej hrobky Eumachie, ktorý by dokazoval prítomnost’ uloženia ostatkov jedinej z týchto osôb. Práve v kontexte schol ako komemoratívnych stavieb je v porovnaní s helenistickými exedrami znovu podivuhodná odchýlka vo veci samotnej výzdoby týchto štruktúr. Zatial' čo na východe ríše bolo bežné umiestňovanie heroizovaných sôch konkrétnych rodín občas s prídavným mytologickým výjavom na operadlách exedier, v Pompejách tento výzdobný motív absolútne chýba.

\section{Záver}

V otázke kultúrneho osídlovania Pompejí je zrejmé, že toto antické mesto možno považovat' za rímske v pravom slova zmysle len necelé dve storočia pred výbuchom Vezuvu. Multikulturalita tohto osídlenia je na základe archeologických a epigrafických nálezov badatelná i na sklonku existencie Pompejí. V kontexte pompejských schol je zodpovedanie otázok položených v úvode práce značne komplikované. Spoločným prvkom týchto štruktúr v rámci Pompejí je ich umiestnenie na prominentných miestach v tesnej blízkosti mestských brán ${ }^{26}$ a výstavba nariadená z poverenia rady decuriones. V kontexte osôb spojených s výstavbou schol je jediným spoločným prvkom ich aristokratické zázemie a výkonné funkcie v kontexte riadenia mesta. Vzhl’adom na chýbajúce dôkazy uloženia ostatkov zosnulých ${ }^{27}$ je potrebné prestat pomenovávat tieto štruktúry ako hrobky. Vhodnejším názvom pre tieto štruktúry je v tom prípade komemoratívna stavba alebo funerálny pamätník oslavujúci život, verejné funkcie či činnost̉ zosnulých v rámci mesta. Ohl’adom datácie je otázne, či je možné udávat výstavbu týchto štruktúr do augustovského obdobia, vzhladom na exempláre, ktoré mohli byt hypoteticky datačne mladšie a spadat’ až do fláviouského obdobia.

1) Sčítanie ludu a súpisu majetku, na základe ktorého boli občania revidovaný do jednotlivých majetkových skupín (Franklin 2008, 522).

2) Liv. IX.38.

3) Strab. V.4.

4) Plin. HN.III.9.

5) Zmienené diela Strabóna, Livia vyšli až na prelome letopočtov (Svoboda 1973, 348; 589) v období prerodu rímskej republiky v cisárstvo (obdobie zvané ako raný principát), zatial' čo dielo Plinia st. vyšlo až v 70tych rokoch n.l. (Conte 2003, 442) v období vlády dynastie Fláviovcov. V tomto období patria Pompeje pod rímsku ríšu a obyvatelstvo je už z väčšej časti latinizované. Je teda diskutabilné do akej miery je možné považovat tieto zdroje za hodnoverné.

6) Obrazové doplnenie tejto typológie bohužial' nebude prítomné z dôvodu nekvalitného prevedenia v originálnom článku. Grafické znázornenie tejto typológie je možné dohladat v článku od Lydy Borelli, ktorý je uvedený v bibliografí alebo v autorkinej diplomovej práci, str. 23 [Molnárová, M. 2019: Polkruhové 
štruktúry typu schola v Pompejách a vybrané paralely vo východnom Stredomorí (Magisterská práca). Masarykova Univerzita v Brne, Filozofická fakulta, Ústav archeológie a muzeológie, Katedra klasickej archeológie].

7) Borelliová zarad’uje túto scholu až do druhého typu, avšak je otázne, či by práve vzhladom na prítomnost? zadného murovaného obkolesenia spolu so susednou scholou Marca Tullia nemala táto schola patrit do prvého typu. Na tejto schole ale chýba centrálny zadný výstupok.

8) V ostatných prípadoch boli dedikačné nápisy vytesané do mramorovej dosky, ktorá bola umiestnená na schole alebo v jej tesnej blízkosti.

9) Radenie tejto scholy do druhej typologickej skupiny je ale otázne, vid' poznámka č. 10.

10) V kontexte centrálneho zadného výstupku ide o scholu Marca Tullia, ohladom zadného obkolesenia ide znovu o scholu Marca Tullia a scholu Marca Alleia Minia za Stabijskou bránou a v kontexte priehlbiny uprostred priesečnice ide o scholu Mamie za Herkulánejskou bránou a opät o scholu Marca Alleia Minia.

11) Ground Penetrating Radar.

12) [Ar]elliae N(umeri) f(illiae) Tertullae / Vei Frontonis Huic decurion(es) / locum sepulturae post mortem / dederunt et funus ex p(ecunia) p(ublica)/ decre(verunt) (Spano 1910, 405).

13) L(ucius) Sepunius L(ucii) filius Sandilianus / M(arcus) Herennius A(uli) f(ilius) Epidianus / duovir(e) $\mathrm{i}($ ure) d(icundo) sc(h)ol(am) et horol(ogium) / d(e) s(ua) p(ecunia) f(aciendum) c(uraverunt) (CIL X 831).

14) N(umerius) Herennius N(umeri) f(ilius) Men(enia) / Celsus d(uo) v(ir) i(ure) d(icundo) iter(um) prae$\mathrm{f}($ ectus $)$ / ( fabr(orum) / Aesquilliae C(ai) f(iliae) Pollae / uxori. Vixit annos XXII. / Locus sepulturae publice datus / d(ecreto) d(ecurionum) (Spano 1910, 390).

15) $\mathrm{M}($ arco) Alleio Q(uinti) f(ilio) Men(enia tribu) Minio II v(iro) i(ure) d(icundo) locus sepulturae publice datus ex d(ecreto) d(ecurionum) (Vivanet 1899, 280).

16) A(ulo) Veio M(arci) f(ilio) IIvir(o) i(ure) d(icundo) / iter(um) quinq(uennali) trib(uno) / milit(um) ab $\operatorname{popul}(\mathrm{o})$ ex d(ecreto) d(ecurionum) (CIL X 996).

17) $\mathrm{M}($ arco) Tullio / M(arci) F(ilio) / ex d(ecreto) d(ecruionum) (Campbell 2015, 300).

18) $\mathrm{M}$ (arcus) Tullius (M)arci f(ilius) d(uum) v(ir) i(ure) d(icundo) ter(tium) quinq(uennalis) augur tr(ibunus) mil(itumu) / apop(ulo) aedem Fortunae August(ae) solo et peq(unia) sua (CIL X 820).

19) Manželom Arellie Tertully bol Veius Frontus a manželom Aesquillie Polly bol Numerius Herennius Celsus.

20) $\mathrm{M}[\mathrm{am}$ ?]miae $\mathrm{P}($ ubli) f(iliae) sacerdoti publicae locus sepultur(ae) datus decurionum decreto (CIL X 998).

21) L(ucius) Sepunius L(uci) f(ilius) / Sandilianus / M(arcus) Herennius A(uli) f(ilius) / Eidianus / duovir(i) $\mathrm{i}$ (ure) d(icundo) /d(e) s(ua) p(ecunia) f(aciendum) c(uraverunt) (CIL X 802).

22) $\mathrm{M}(\mathrm{a})$ mia $\mathrm{P}($ ublii) f(ilia) sacerdos public(a) geni[(o) Aug(usti) s]olo et pec[(unia) sua] (CIL X 816).

23) Eumachia L(uci) f(ilia) sacerd(os) publ(ica) nomine suo et / M(arci) Numistri Frontonis fili(i) chalcidicum cryptam porticus Concordiae / Augustae pietati sua pecunia fecit eademque dedicavit (CIL X 810, 811).

24) Osoby, ktoré sa živili čistením prádla.

25) Eumachiae L(uci) f(iliae) / sacerd(oti) publ(icae)/ fullones (CIL X 813).

26) S výnimkou scholy na Trojuholníkovom fóre, ktorá je v rámci mestskej zástavby.

27) S výnimkou hrobky Eumachie. 


\section{Bibliografia}

\section{Antické pramene:}

Strabón V, 4 (Geógrafika). Hamilton, H. C. - Falconer, W. 1903, London.

Plinius, N. H. III, 9 (Naturalis Historia). Bostock, J. Riley, H. T. 1855, London.

Livius IX, 38 (Ab Urbe Condita). Foster, B. O. 1926, London.

Adams, J. N. 2003: Bilingualism and the Latin Language. Cambridge.

Aktas, S3. 2008: Tombs of the Exedra Type and Evidence from the Pataran Examples, Adalya No. XI, 235-262.

Allison, P. M. 2001: Placing Individuals: Pompeian Epigraphy in Context, Journal of Mediterranean Archaeology vol. 14, 53-74.

Astour, M. C. 1985: Ancient Greek Civilization in Southern Italy, Journal of Aesthetic Education vol. 19, 23-37.

Bartoněk, A. 1975: Greek dialects of ancient Apennine peninsula. In: Češka, J. (ed.), Classica atque mediaevalia Jaroslao Ludvíkovský octogenario oblata. Brno, 17-36.

Borrelli, L. 1937: Le tombe di Pompei a schola semicircolare. Napoli.

Bradley, P. 2013: Cities of Vesuvius: Pompeii and Herculaneum. Cambridge.

Campbell, V. L. 2015: The Tombs of Pompeii. Organization, Space and Society. New York.

Carpiceci, A. C. 1979: Pompeii 2000 years ago. Florence.

Carrington, R. C. 1932: The Etruscans and Pompeii, Antiquity vol. 6, 5-23.

Castrén, P. 1975: Ordo Populusque Pompeianus. Polity and Society in Roman Pompeii. Rome.

Conte, G. B. 2003: Dějiny římské literatury. Praha.

Cooley, A. E. - Cooley, M. G. L. 2004: Pompei: A Sourcebook. London \& New York.

Cooley, A. E. - Cooley, M. G. L. 2013: Pompeii and Herculaneum: A Sourcebook. London \& New York.

Descoeudres, J - P. 2008: History and Historical Sources. In: Foss, P. - Dobbins, J. J. (eds.), The World of Pompeii. London \& New York, 9-27.

Dillon, S. 2010: The Female Portrait Statue in the Greek World. Cambridge.
Dobbins, J. J. 2008: The forum and its dependencies. In: Foss, P. - Dobbins, J. J. (eds.), The World of Pompeii. London \& New York, 150-183.

Dyer, T. H. 1870: Pompeii. Its History, Buildings and Antiquities. New York.

Emmerson, L. C. 2010: Reconstructing the Funerary Landscape at Pompeii's Porta Stabia, Rivista di Studi Pompeiani vol. 21, 77-86.

Fiorelli, G. 1875: Descrizione di Pompei. Napoli.

Fishwick, D. 1995: The inscription of Mamia again: the cult of the Genius Augusti and the temple of the imperial cult on the Forum of Pompeii, Epigraphica vol. 57, 17-38.

Franklin, J. L. 2001: Pompeis Difficile Est: Studies in the Political Life of Imperial Pompeii. Michigan.

Franklin, J. 2008: Epigraphy and Society. In: Foss, P. - Dobbins, J. J. (eds.), The Lost World of Pompeii. London \& New York, 518-525.

Franklin, J. L. 2004: Fragmented Pompeian Prosopography: The Etnicing and Frustrating Veii, The Classical World vol. 98, No. I, 21-29.

Giuntoli, S. 1989: Art and History of Pompeii. Florencia.

Gordon, M. L. 1927: The Ordo of Pompeii, The Journal of Roman Studies vol. 17, 165-183.

Hellström P., 2007: Labraunda. Karya Zeus Labraundos Kutsal Alani Gezi Rehberi. Istanbul

Henderson, T. K. 2014: Constructing an Oscan Cityscape: Pompeii and the Eítuns Inscription. Urban Dreams and Realities in Antiquity, Remains and Representations of the Ancient City vol. 375, 99-120.

James, S. L. - Dillon, S. 2015: A Companion to Women in the Ancient World. Chichester, West Sussex.

Jashemski, W. F. 2002: The Natural History of Pompeii. Cambridge \& New York.

Jilek, J. 2007: Několik poznámek ke skyfům typu Meroe z Krakovan-Stráží a Ostrovan. In: Sborník prací filozofické fakulty brněnské univerzity, M řada archeologická roč. 54-55 2005-2006. Brno, 75-103.

Kay, S. - Martin, L.A. - Albiach, R. 2018: Investigation the archaeology of death at Pompeii. The necropolis and fugitives of the Nolan Gate. In: Antropologia e Archeologia a Confronto: Archeologiae Antropologia della Morte. 1. La regola dell'eccezione. Atti dell'Incontro Internazionale di studi. Roma, 413-424. 
Kay, S. - Martin, L. A. - Albiach, R. 2017: Pompeii: Porta Nola Necropolis Project (Comune di Pompei, Provincia di Napoli, Regione Campania), Papers of the British School at Rome vol. 85, 324-327.

Kockel, V. 1983: Die Grabbauten vor dem Herkulaner Tor in Pompeji. Mainz am Rhein.

Kristensen, T. M. 2018: Mobile situations: Exedrae as stages of gathering in Greek sanctuaries, World Archaeology vol. 50, 86-99.

Ling, R. 2008: Development of Pompeii's public landscape in the Roman period. In: Foss, P. - Dobbins, J. J. (eds.), The World of Pompeii. London \& New York, 119-128.

Mackenzie, W. M. 1910: Pompeii. London.

Maiuri A., 1960: Pompei. Enciclopedia dell'Arte Antica, Classica e Orientale vol. 6, Rome.

Maiuri, A. 1978: Pompeii. Rome.

Mau, A. 1890: Scavi fuori porta Stabiana, Scavi di Pompeii, 277-284.

Mau, A. 1904: Pompeii: It's Life and Art. New York.

Mommsen, Th. 1883: Corpus Inscriptionum Latinarum vol. X.1. Berolini.

Neumann, S. 2011: Steinerne Sitzbänkeund prachtvolle Räume - Exedren in hellenistischen Pergamon. In: von Grüßinger, R. - Kästner, V. - Scholl, A. (ed.), Pergamon - Panorama der antiken Metropole. Berlin, 309-311.

Nissen, H. 1877: Pompeianische Studien zur Städtekunde des Altertums. Leipzig.

Nohlen, K. 2011: Ein Tempel für den Kaiserkult - Das Trajaneum von Pergamon. In: von Grüßinger, R. - Kästner, V. - Scholl, A. (ed.), Pergamon - Panorama der antiken Metropole. Berlin, 159-173.

Nonnis, D., - Ricci, C. 1999: Vectigalia municipali ed epigrafia: un caso dall'Hirpinia. Il capitolo delle entrate nelle finanze municipali in Occidente ed in Oriente. In: Actes de la Xe Rencontre franco-italienner sur l'épigraphie du monde romain (Rome, mai 1996), Collection de l'École française de Rome vol. 256. Rome, 41-59.

Reinfjord, K. 2011: Communicating Conspicuous Consumption in Roman Pompeii, Rivista di Studi Pompeiani vol. 22, 15-24.

Richardson, L. 1988: Pompeii. An Architectural History. Baltimore \& London.
Scott, M. 2013: Space and Society in the Greek and Roman Worlds. Cambridge.

Sears, G. - Keegan, P. - Laurence, R. 2013: Written Space in the Latin West, $200 \mathrm{BC}$ to AD 300. London \& New York.

Spano, G. 1910: Scavo nel giardino annesso alla tomba di M. Tullio, fuori Porta di Stabia, Notizie degli Scavi di Antichitá vol. VII, 567-569.

Spano, G. 1910: Relazione degli scavi eseguiti negli anni 1908 e 1909, Notizie delgi scavi di Antichitá vol. VII, 376-399.

Spano, G. 1910: Scavi fuori Porta del Vesuvio, Notizie degli Scavi di Antichitá vol. VII, 399-416.

Stillwell, R. 2017: The Princeton Encyklopedia of Classical Sites. Princeton.

Svoboda, L. 1973: Encyklopedie Antiky. Praha.

Swain, S. 1991: Plutarch, Hadrian and Delphi, Zeitschrift für Alte Geschichte vol. 40, 318-330.

Tartaron, T. F. 2014: Cross-Cultural Interaction in the Greek World: Culture Contact Issues and Theories. In: Smith C. (ed.), Encyclopedia of Global Archaeology. New York, 1804-1821.

Viscogliosi, A. 2019: From Pergamon to Rome and from Rome to Pergamon: A Very Fruitful Architectural Gift. In: Hemingway, S. - Karoglou, K. (eds.), Art of the Hellenistic Kingdoms: From Pergamon to Rome. New York, 91-98.

Vivanet, F. 1889: Pompei. In Notizie degli Scavidi Antichitá, vol XXIII, 278-281.

Ward, R. B. 1998: The Public Priestess of Pompeii, The Early Church in Its Context vol. 90, 318-334. Welch, K. E. 2008: Pompeian men and women in portrait sculpture. In: Foss, P. - Dobbins, J. J. (eds.), The World of Pompeii. London \& New York, 550-584.

Westfall, C. W. 2008: Urban planning, roads, street and neighborhoods. In: Foss, P. - Dobbins, J. J. (eds.), The World of Pompeii. London \& New York, 129-139.

Wilkinson P. 2017: Pompeii: An Archaeological Guide. London \& New York.

Will, E. L. 1979: Women in Pompeii, Archaeology, vol. 32, 34-43.

Zanker, P. 1998: Pompeii: Public and Private Life. Cambridge. 


\section{Schola-type structures in Pompeii - a symbol and display of the power of pompeian aristocracy on the examples of structures designed for rest}

The presented article deals with the semi-circular schola-type structures in Pompeii which, from a functional point of view, served to rest. Attention is paid to people who were associated with the construction of these structures, particularly to their cultural origin, possible building activity and public offices held by these persons. The introductory chapter describes the historical and cultural development in the Gulf of Naples and Pompeii on the basis of preserved archaeological and epigraphic evidence. This part of the text elucidates how this area has been colonised by the population from Greece, Etruria and the inland of Campania. The aim of this chapter was to point out the multiculturalism of Pompeii during its development, which was still visible at the end of the town's existence. It is obvious that after the one or the other party has lost the fight for dominance and the defeated population was expelled, none of the above-mentioned cultures has moved completely out of this territory. The main chapter, which was dedicated to schola-type structures, was divided into several thematic areas, addressing the problems of classification of scholae as tombs and the problems of their dating. This part is followed by a subchapter dealing with individual public offices of persons related to Pompeian scholae. The offices can be divided by family affiliation into magisterial offices held by men and by wives to whom scholae were dedicated by their husbands, and offices of public priestesses held by other women. The main chapter ends with a description of cultural origin of individual persons whose family affiliation and cultural origin are known. This part of the text is focused on the division of persons according to Greek, Etruscan, Campanian, Latin or unknown cultural origin. The last chapter deals with exedrae, which are supposed to have inspired the Pompeian scholae. It briefly describes selected examples of exedrae from the Hellenistic and Roman periods in the Eastern Mediterranean. Focus is laid on Hellenistic exedrae and their placement in funerary, urban or sacred areas. The text gives examples from the Hellenistic and Roman periods, which provided for the propaganda of individual kings and emperors who sponsored their construction.

\section{Mgr. Miriam Molnárová}

- Ústav archeologie a muzeologie,

Filozofická fakulta, Masarykova univerzita,

A. Nováka 1, 60200 Brno, Česká republika

428633@mail.muni.cz 